\title{
Leader
}

\section{Cell cycle regulators: mechanisms and their role in aetiology, prognosis, and treatment of cancer}

\author{
R J A M Michalides
}

Division of Tumour Biology, the Netherlands Cancer Institute, Plesmanlaan $121,1066 \mathrm{CX}$ Amsterdam,

Netherlands

R J A M Michalides

Correspondence to: Dr Michalides. email: rmichal@nki.nl

Accepted for publication 16 March 1999
Tumour cells have sustained derailments in growth control, have escaped from immunological clearing systems, and have acquired immortality as a result of an accumulation of genetic alterations that provide these cells with a selective advantage over others (fig 1). Tumour development is therefore a disease of the DNA and is heritable when these genetic alterations have occurred in the reproductive cells. Progression in tumour development is the result of a stepwise accumulation of genetic abnormalities. The exact number of abnormalities involved in each different tumour type is not known, but in the development of colonic cancer at least seven alterations are involved. ${ }^{12}$

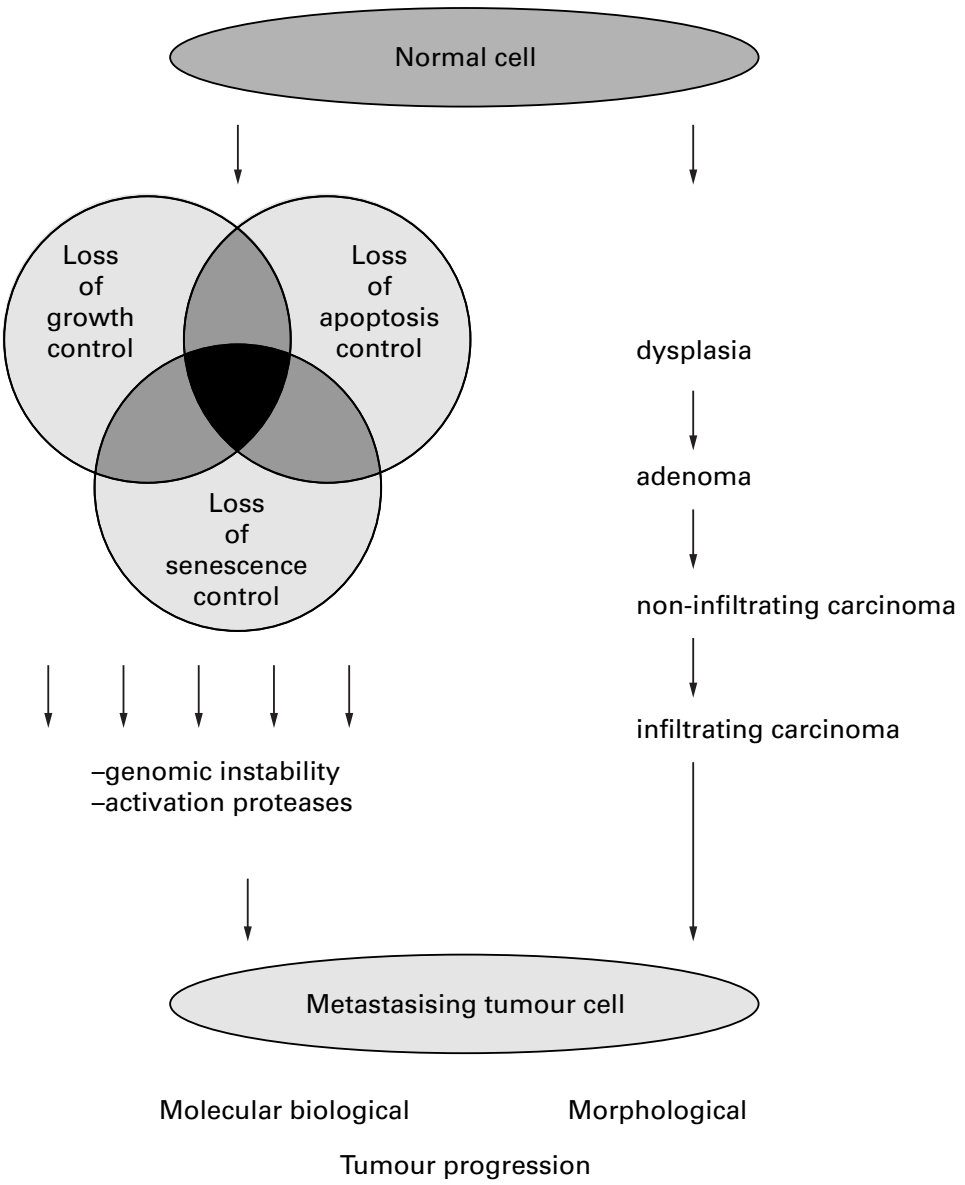

Figure 1 Molecular biological and morphological tumour progression.
Over the last 20 years developments in cellular and molecular biology have revealed many such alterations in tumour cells. The variety among these would render it impossible to devise a general strategy for diagnosis and treatment that is based upon individual alterations, unless these alterations were to end up in a central control system which ultimately determines the fate of cell growth. Also for practical reasons it is essential for pathologists and clinicians either to distinguish common themes among the numerous genetic alterations or to recognise the most relevant ones. This overview is an attempt to search for such crucial alterations among the numerous possibilities trotted out by cellular and molecular biologists, and to seek support for them in recent reports on immunopathology and treatment. The overview is far from complete, and I shall only attempt to demonstrate that these common themes are starting to assist us in the diagnosis and treatment of cancer.

\section{Control of cellular proliferation}

Growth of cells is the net result of cell duplication, differentiation, and cell death, which are mutually regulated. Cells enter the cell cycle and commit to DNA synthesis in response to external factors, including growth factors and cellular adhesion. During the first phase of the cell cycle, G1, cells are responsive to these

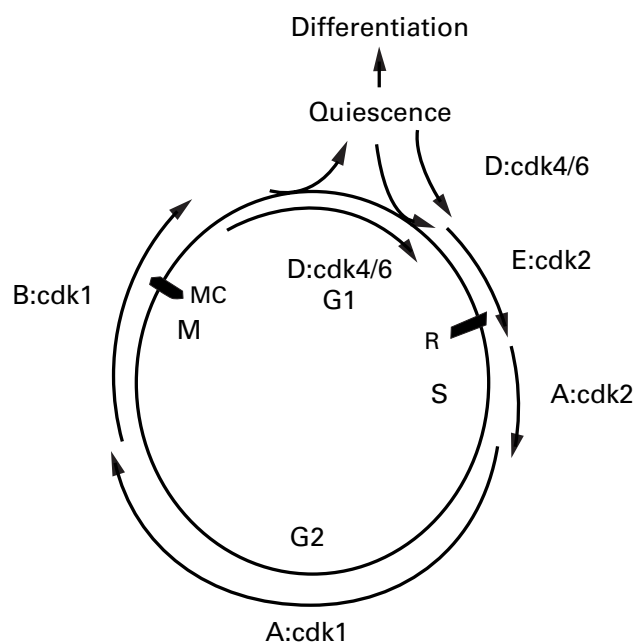

Figure 2 Cell cycle progression. cdk, cyclin dependent kinase; MC, mitotic checkpoint. 
A

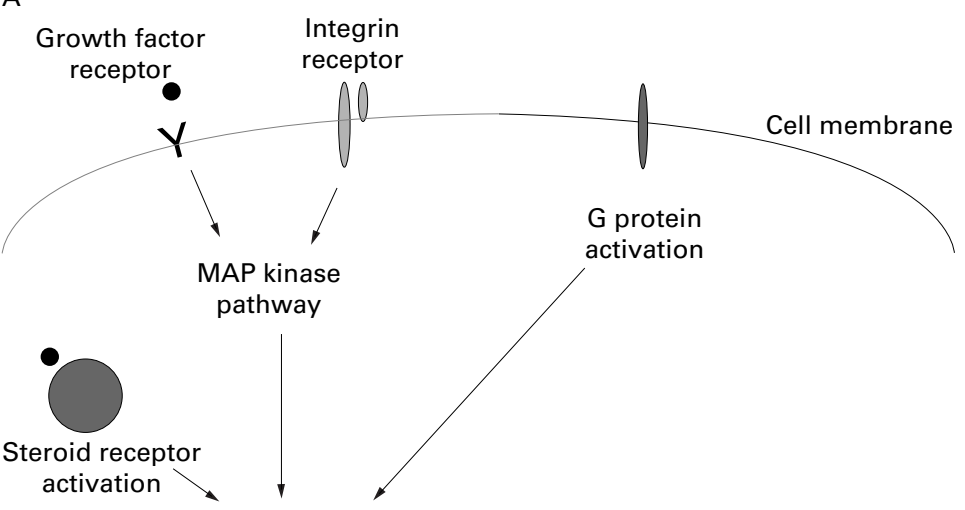

Nucleus

Transcription co-factor

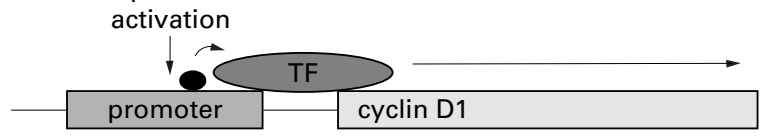

B

Cyclin D1 promoter:

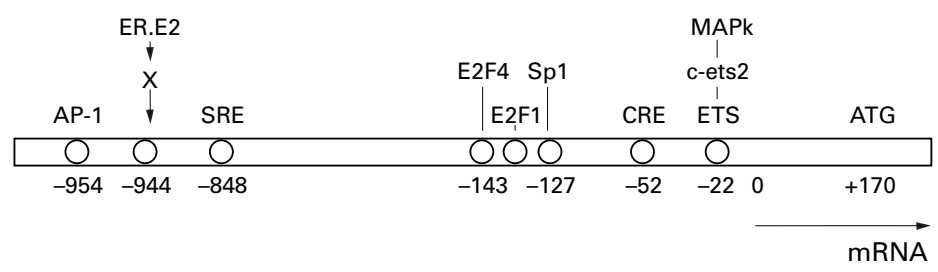

Cyclin D1 mRNA:

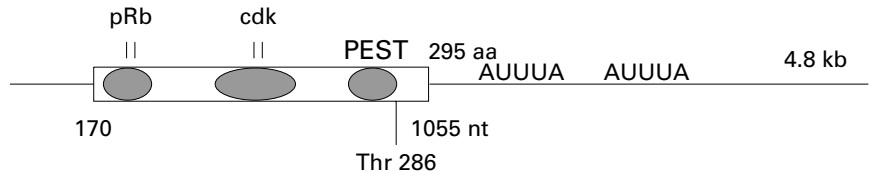

Figure 3 (A) Activation of signalling pathways leads to transcription of cyclin D1. (B) Characteristics of the promoter, $m R N A$, and the protein of cyclin D1. MAP, mitogen activated protein; TF, transcription factor.

mitogenic stimuli and are dependent on them in order to reach a critical restriction point, termed $\mathrm{R}$, at the end of $\mathrm{G} 1 .{ }^{3}$ Beyond the restriction point $\mathrm{R}$, cell cycle transition becomes autonomous. Transition through the cell cycle is regulated by the activities of cyclin dependent kinases (cdk) and their inhibitors, cdk associated inhibitors (cki) (fig 2).

A cdk is active as a serine/threonine kinase if it associates with a cyclin protein and becomes activated by phosphorylation and dephosphorylation through cyclin activated kinase (CAK), wee1-kinase, and cdc25 phosphatase. ${ }^{45}$ This complex cdk activation mechanism provides multiple levels of control. Cyclin proteins are only present during particular phases of the cell cycle. This is the result of specific induction and elimination of these proteins in the cell cycle. Induction of cyclins starts when cells enter the cell cycle from a quiescent state. It requires growth factors and adherence of cells to extracellular matrix components such as collagen or fibronectin. Binding of growth fac- tors to receptors, either at the surface of the cells (for instance for epidermal growth factor) or in the cytoplasm (in the case of steroids), triggers a cascade of events by which the signal of the ligand binding to the receptor is transmitted into the nucleus, resulting finally in the activation of transcription factors (fig $3 \mathrm{~A}$ ). The number of intermediates in each of these signal transduction pathways varies, and mutations in their genes provide ample opportunities for continuous stimulation.

All these signal transduction pathways finally activate transcription factors that are responsible for transcription of, among other things, the cyclin D gene, coding for the first cyclin protein acting in G1. Three different cyclin Ds have been identified (D1-3); their distribution is more or less cell type specific, with cyclin D1 being expressed in most epithelial and fibroblast cells and cyclin D3 in lymphoid cells. ${ }^{6}$ The promoter of the cyclin D1 gene contains multiple DNA binding sites for transcription factors which are either induced or activated by growth factors to regulate its expression (fig 3B)..$^{7-13}$ Adhesion of cells onto extracellular matrix components also induces transcription of cyclin D1, most probably through the mitogen activated protein kinase (MAPK) pathway, which becomes activated when integrin receptors bind to extracellular matrix components. ${ }^{14-17} \mathrm{D}$ type cyclins are rate limiting for cell cycle progression, since enforced overexpression of cyclin D1 accelerates G1 transition, whereas, conversely, inactivation of cyclin D1 by microinjection of antibodies or antisense DNA constructs induces a G1 arrest. ${ }^{18-20}$ Cyclin D1 protein associates with cdk4 or cdk6, and this complex is then positively regulated by CAK and cdc 25 and negatively by wee $1 / \mathrm{mik}$ kinase and cyclin kinase inhibitors (see below). The final target of an activated cyclin D:cdk4 or cdk6 kinase complex is the retinoblastoma protein, $\mathrm{pRb}^{21}$ Phosphorylation of this protein releases E2F transcription factors which are required for the transcription of $\mathrm{E} 2 \mathrm{~F}$ responsive genes, including those with proteins involved in DNA synthesis and mandatory for $S$ phase progression. $^{21}$

E2F represents a family of at least five different transcription factors which bind to hypophosphorylated $\mathrm{pRb}$ or to related p107 and p130 proteins. $^{22}$ pRb appears unique among these $\mathrm{E} 2 \mathrm{~F}$ binding proteins, since elimination of $\mathrm{pRb}$ alone is sufficient to liberate abundant E2F activity to render growth of cells growth factor independent. ${ }^{23}$ Once activated, each of these E2Fs acts as a transactivator and mediates transcription of $\mathrm{E} 2 \mathrm{~F}$ responsive genes, among which are cyclins D1, E, and A. The promoters of cyclins D1, E, and A contain E2F binding sites. $^{824}$ Thus once cyclin $\mathrm{D} 1:$ cdk 4 is active it generates more cyclin D1 by a positive feedback mechanism. Further progression through $\mathrm{G} 1$ to restriction point $\mathrm{R}$ requires activity of cyclin $\mathrm{E}$, and passage through the $S$ phase demands cyclin A activity, each in a complex with cdk2. Induction of these two cyclins is depending on E2F, ${ }^{25} 26$ implying that once cyclin D1:cdk4 activity has 


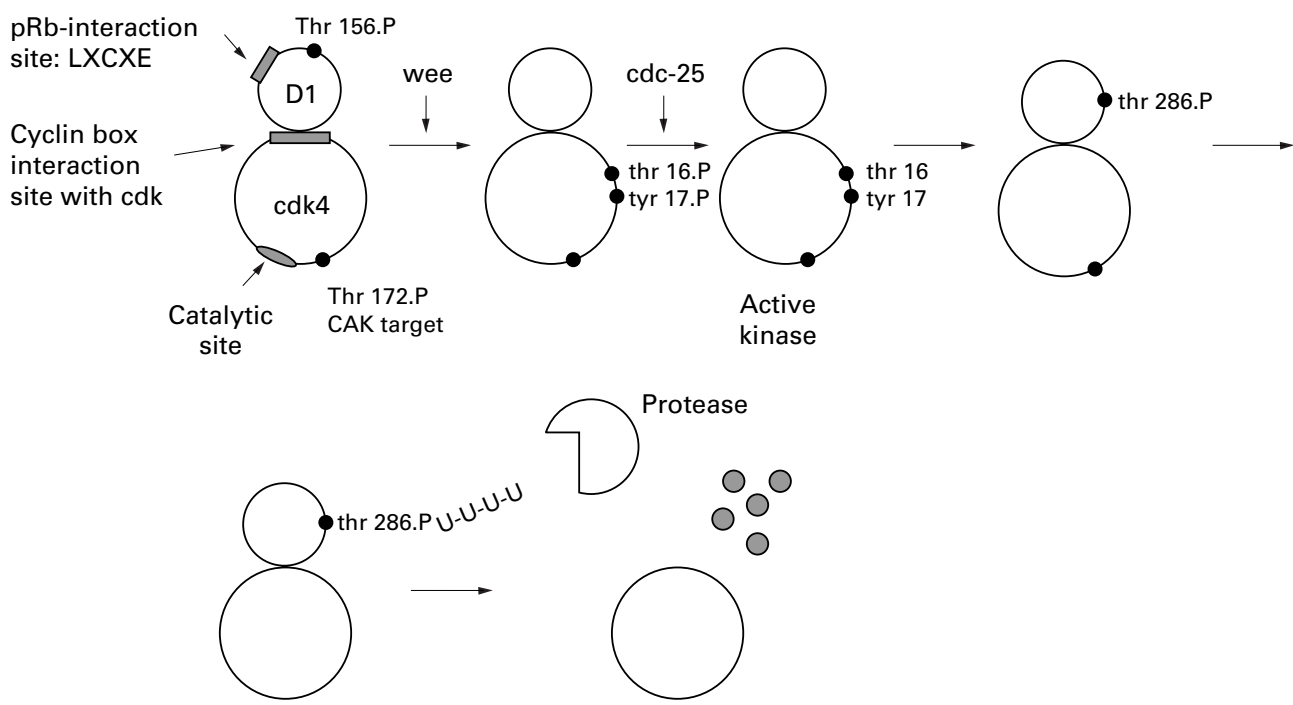

Figure 4 Activation and destruction of the cyclin D1:cdk4 kinase complex.

set the G1 regulatory system into motion, cyclin E:cdk and cyclin A:cdk activities are induced and cell cycle transition may occur (fig 2). Each of these G1 cyclin:cdk complexes phosphorylates $\mathrm{pRb}$, however, at different sites $^{27}$ and with different effects. ${ }^{28}{ }^{29}$ The different effects may result from the release of different $\mathrm{E} 2 \mathrm{~F}$ members from the $\mathrm{pRb}$ or $\mathrm{pRb}$ family members $^{30-32}$ or be due to specific activities of each of the cyclins (see below), or both of these.

Activity of G1 cyclins is directly linked to DNA synthesis, since cdc6 protein, which is essential for DNA replication in $S$ phase, is induced by $\mathrm{E} 2 \mathrm{~F}$ that is released by cyclin $\mathrm{D}$ or cyclin E:cdk activity, but not by cyclin A kinase activity. ${ }^{33-35}$ The latter is more likely to be involved in the release of restrictive components from the DNA replication complex during $S$ phase. ${ }^{36}$ Activation of G1 cyclins results in induction of cyclin B during G2, which becomes associated with cdk1 that also binds to cyclin A. Their combined activities mediate transition through $\mathrm{G} 2 / \mathrm{M}$ phase of the cell cycle. $^{37} 38$

Degradation of cyclin D either results from specific degradation of its $\mathrm{mRNA}^{39}$ or from degradation of the protein by proteases after recognition of degradation specific PEST sequences at the $\mathrm{C}$ terminus (fig $3 \mathrm{~B}$ ) or through ubiquitin dependent proteasomal degradation (fig 4). Cyclins serve as a substrate of their own cyclin:cdk complex; phosphorylation of cyclins creates a target for ubiquitin dependent, protease mediated degradation of cyclins D1, E, A, and B. ${ }^{41-43}$ This degradation of cyclins terminates their action and provides a one way direction to the cell cycle.

Thr-156 is the phosphorylation site of cyclin D1 by a yet unknown kinase, which is mandatory for phosphorylation of Thr-172 by CAK and for entry into the nucleus. ${ }^{40}$

Stimulation of growth is mediated by the action of the cyclin:cdk, whereas inhibition of growth is imposed by the cki suppressor proteins (fig 5). ${ }^{4-46}$ The cki include two families: first, the INK4 family which encompasses $\mathrm{p} 16^{\mathrm{INK} 4 \mathrm{~A}}, \mathrm{p} 15^{\mathrm{INK} 4 \mathrm{~B}}, \mathrm{p} 18^{\mathrm{INK} 4 \mathrm{C}}$, and $\mathrm{p} 19^{\mathrm{INK} 4 \mathrm{D}}$, all of which inhibit cyclin D:cdk4 kinase activity by binding to the cdk 4 site which associates with cyclin $\mathrm{D}^{47}$; second, the CIP/Kip family members-including p21, p27, and p57which bind to all cyclin:cdk complexes and inhibit their activity. There is regulation of the cki at various levels, by transcription, by post-translational modulation, and by a shift in their cyclin:cdk targets. When cells enter the cell cycle from quiescence, growth factors induce cyclin D1 expression and formation of the cyclin D:cdk4 complex. This increased complex formation will absorb cki-p27 until a point is reached where excess cyclin D:cdk4/6 complex has titrated out all available p27. From this point on, cyclin D:cdk4/6 will function as an active kinase and generate free E2F, which induces transcription of cyclin E. The story is now reiterated: increasing cyclin E:cdk2 levels titrate out p27 by which unbound, active cyclin E:cdk2 is generated. ${ }^{48}{ }^{49}$

CIP-cki complexes inhibit cyclin:cdk with different efficiency and affinity: p27 inhibits cyclin A:cdk2 more efficiently than cyclin $\mathrm{D}: \mathrm{cdk}^{50}$ whereas p21 inhibits both with equal efficacy; cki-p27 binds to cyclin A:cdk2 with an approximately 10 -fold higher affinity than to cyclin D2:cdk4, and p21 has a higher affinity for cyclin D2:cdk4 than for cyclin E:cdk2..$^{51}$ In addition, cellular levels of cki affect inhibition: p21 and p27 in low concentrations stabilise a cyclin D:cdk complex, whereas they inhibit its kinase activity when present in high concentrations. ${ }^{52}$ These data suggest that cyclin D:cdk complexes may function as a catcher for p27 or p21. When cyclin D1 levels increase, cyclin D:cdk complexes absorb more p27/p21 at the expense of its binding to cyclin:cdk2 complexes. This results in G1 transit, and vice versa. Such a shift in targets of cki is the basis of action of transforming growth factor $\beta$ (TGF$\beta$ ), anti-oestrogens, or rapamycin: TGF- $\beta$ stabilises cki-p $15,{ }^{53}$ which preferentially binds to cyclin D:cdk. This causes a displacement of cki-p27 from cyclin D1:cdk4 which now becomes associated with cyclin E:cdk2, causing a G1 arrest in epithelial cells. In addition, 


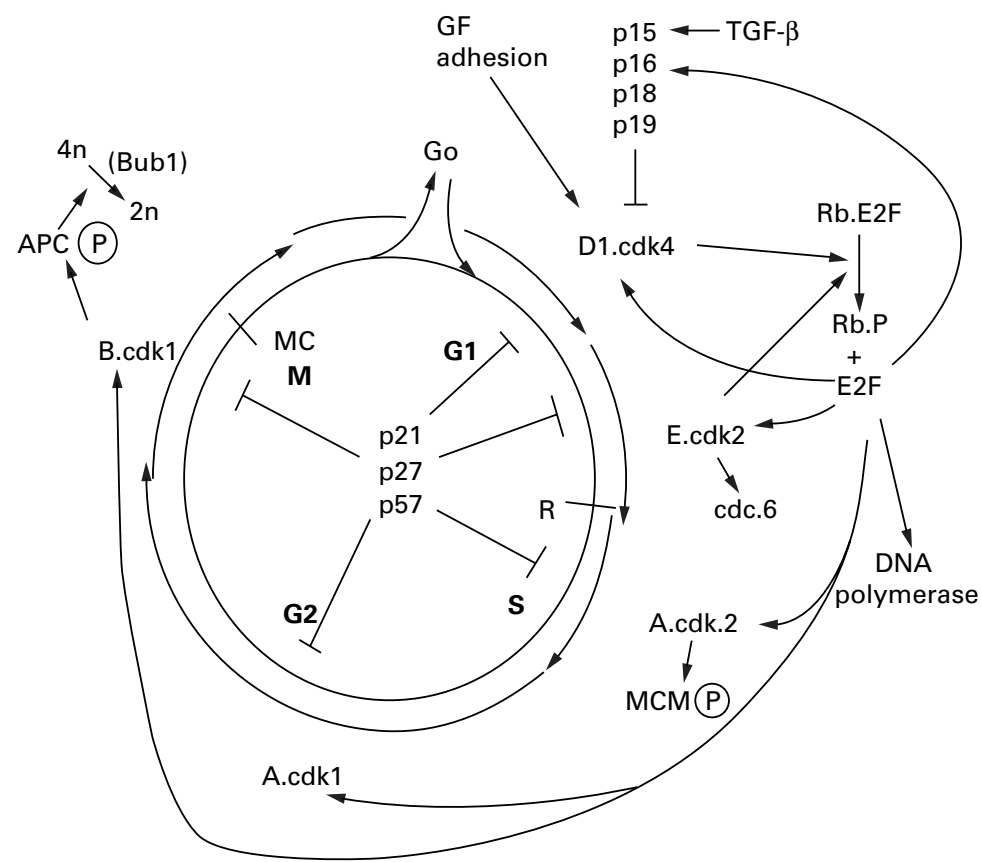

Figure 5 Positive and negative regulators of the cell cycle: the crucial role of E2F.

arrest of oestrogen receptor positive cells by anti-oestrogens reduces protein levels of cyclin D1, whereby cki-p27 is released from cyclin D1:cdk4 complexes; it now becomes associated with cyclin E:cdk2, thereby causing a G1 arrest. $^{54}$ Also, rapamycin delays accumulation of cyclin D1 mRNA, which leads to impaired formation of cyclin D1:cdk4 complexes. This results in a retargeting of cki-p27 to cyclin E:cdk2, thereby causing a rapamycin induced $\mathrm{G} 1$ arrest. ${ }^{56}$

As well as G1/S, G2/M transition is also influenced by cki $\mathrm{p} 21$, depending on the status of $\mathrm{Rb}$. In $\mathrm{Rb}+/+$ cells, $\mathrm{p} 21$ expression causes a G1/S arrest, whereas a G2 arrest by p21 is more prominent in $\mathrm{Rb}-/-$ cells. $^{57}{ }^{58}$ Induction of $\mathrm{p} 21$ occurs in both a p53 dependent and a

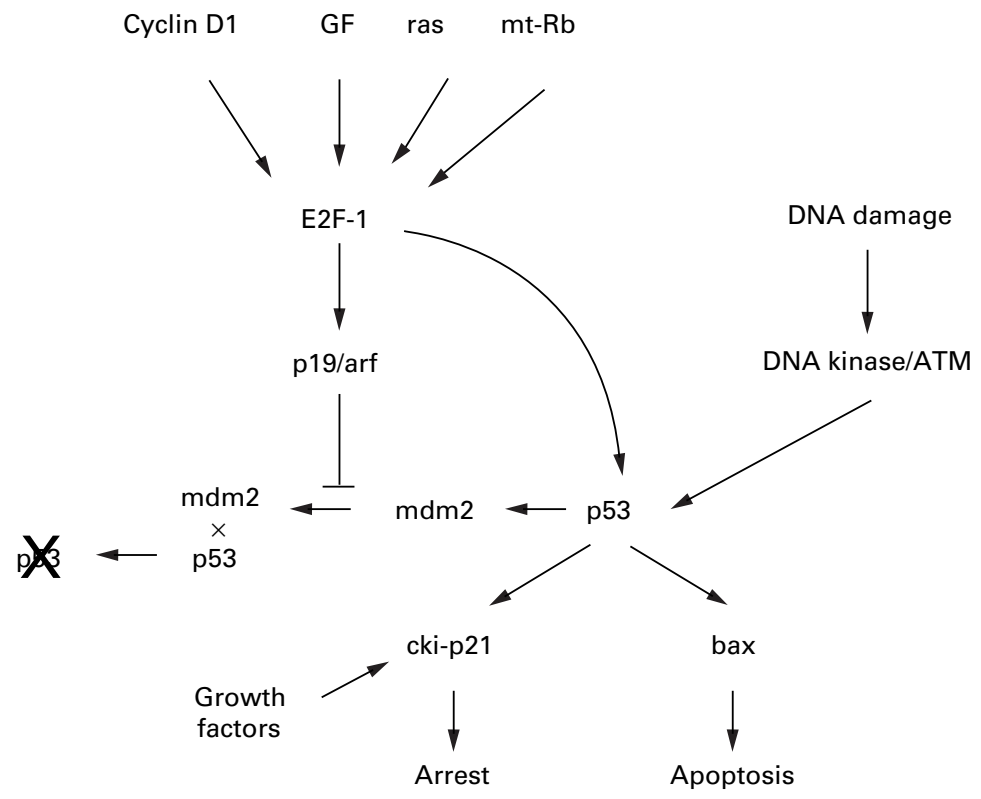

Figure 6 The $E 2 F-p 19^{4 R F}-p 53$ connection between growth control, growth arrest, and apoptosis. p53 independent manner, where the p53 protein is a transcription factor induced upon DNA damage. Expression of genes involved in growth arrest (cki-p21) or apoptosis (bax) is promoted by $\mathrm{p} 53 . .^{50}$ The specific response of p53 depends on $\mathrm{Rb}$ status: in Rb-wt cells, p53 induction leads to cell cycle arrest by induction of $\mathrm{p} 21$, whereas $\mathrm{Rb}$ deficient cells bypass the G1 checkpoint and undergo apoptosis.

\section{Links between positive and negative} regulatory circuits

The regulatory circuits in cell cycle control are self restrictive in the way that once a pathway becomes activated, a restraint mechanism is induced in order to terminate the original stimulus. Growth factor stimulation induces expression of cyclins which, after fulfilling their function, induce self mediated destruction. Besides this self fulfilling restraint, growth factors induce expression of cki or of its regulators, thereby preventing excessive activation of the $\mathrm{Rb}$ pathway. These different regulatory circuits provide multiple levels of control in normal cells, but also multiple possibilities for distortion in tumour cells.

\section{The $p 19^{\mathrm{ARF}}-\mathrm{p} 53$ connection}

Action of p53, the "guardian of the genome" 11 or "gatekeeper" of $\mathrm{Rb},{ }^{62}$ is regulated in three ways (fig 6): by DNA damage, by E2F, and in a negative feedback loop by mdm-2/p1 $9^{\text {ARF }}$.

When normal mammalian cells are subjected to stress signals, oxygen deficiency, radiation, DNA damage, or chemotherapeutic drugs, p53 is activated, leading to p53 mediated induction of programmed cell death (for example through bax) or cell cycle arrest (through $\mathrm{p} 21$ ), or both. ${ }^{63}$ The $\mathrm{p} 53$ response to stress may be mediated by DNA dependent protein kinase ${ }^{64}$ or by the ATM kinase, encoded by the gene responsible for ataxia telangiectasia. ${ }^{65}$ E2F also induces p53 expression ${ }^{66}$ which results in cell cycle arrest in $\mathrm{Rb}$-wt cells, and in p53 mediated apoptosis in $\mathrm{Rb}-/-$ cells. ${ }^{67}{ }^{68}$ Furthermore, p53 also induces mdm-2 which subsequently binds and destabilises p53 in a feedback loop control mechanism. ${ }^{69}$ The mdm-2 mediated degradation of $\mathrm{p} 53$ is controlled by protein $\mathrm{p} 19^{\mathrm{ARF}}$, one of the two tumour suppressors encoded for by the INK4A locus on chromosome $9 \mathrm{p} 21 ; \mathrm{p} 19^{\mathrm{ARF}}$ neutralises $\mathrm{mdm} 2^{70}$ and thereby stabilises $\mathrm{p} 53$. Expression of p19 ${ }^{\mathrm{ARF}}$ is activated by E2F1, ${ }^{71-74}$ by which mechanism the two tumour suppressors $\mathrm{pRb}$ and $\mathrm{p} 53$ become linked. ${ }^{75} \mathrm{E} 2 \mathrm{~F}$, which is released from $\mathrm{pRb}$ by cyclin action upon growth factor stimulation, thereby induces p53, which leads to cki-p21, bax, or other apoptosis promoting proteins, and to $\mathrm{mdm} 2$ which halts p53 action. At the same time, growth factors induce $\mathrm{p} 19^{\mathrm{ARF}}$, whereby $\mathrm{mdm} 2$ action is prevented. In this way, acting through $\mathrm{p} 19^{\mathrm{ARF}}, \mathrm{E} 2 \mathrm{~F}-1$ protects cells from oncogenic changes that result in abnormal proliferation, which is independent of DNA damage (fig 6).

It may now become evident how deregulated E2F expression, either by overactivity of cyclin $\mathrm{D} 1: \mathrm{cdk} 4$ or by abortion of $\mathrm{pRb}$, may lead to p53 associated arrest or apoptosis. ${ }^{66-78}$ This 


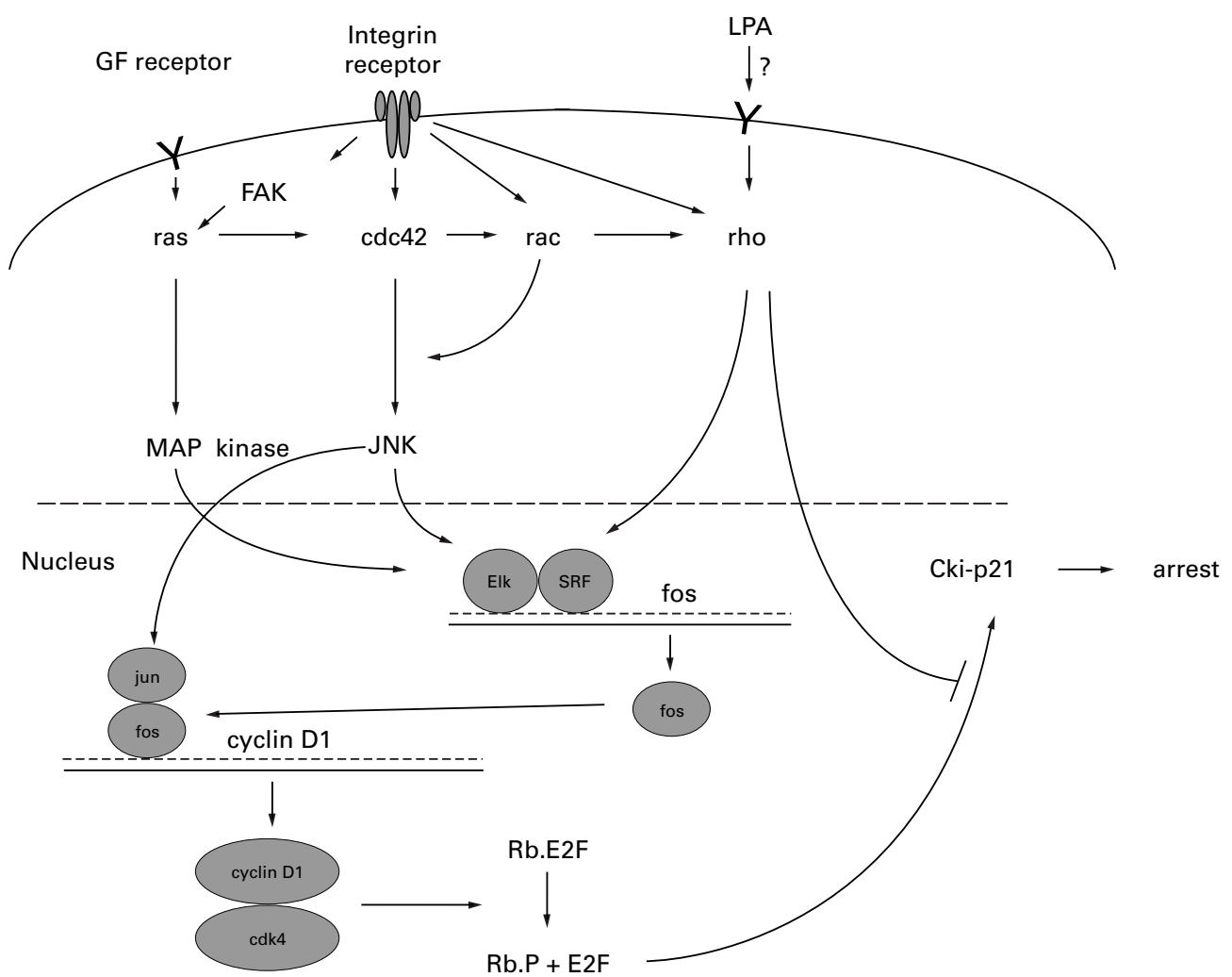

Figure 7 Cooperation between cell adhesion and growth factor stimulation in induction of cyclin D1. FAK, focal adhesion associated kinase; GF, growth factor; LPA, lysophosphatidylic acid.

dual pathway explains also how p53 induced arrest, or apoptosis by cytostatic drugs, taxol, ${ }^{79}$ or irradiation, becomes enhanced by $\mathrm{E} 2 \mathrm{~F}$, either directly by cyclin $\mathrm{D} 1: c d k 4$ activity or $\mathrm{Rb}$ mutation, ${ }^{80-83}$ or indirectly by p16 mutation. ${ }^{84}$ In this way $\mathrm{E} 2 \mathrm{~F}$ stimulation results in enhanced chemo- and radiosensitivity.

\section{Growth factors as inhibitors}

Growth factors do not only stimulate cell proliferation, but they may also act as growth inhibitors, depending on the cell type and on the stimulatory pathway that is involved. TGF- $\beta$ is such an example, being a growth stimulator in fibroblast cells with receptors for TGF- $\beta$, but a negative regulator in epithelial cells. ${ }^{85}$ Not only may the growth factor have different actions, but the pathway activated by a growth factor may also have dual endpoints: E2F activation leads to induction of cyclins, promoting cell cycle transition, as well as to p $19^{\mathrm{ARF}}$ which halts cell cycle transition. In fact, expression of most of the cki is influenced by dual growth regulation, since expression of cki p16 and p21 is dependent on E2F activity, ${ }^{86-92}$ and that of $\mathrm{p} 27$ is enhanced by cyclin D1:cdk4 activity and is thus likely also to be dependent on E2F. ${ }^{93}$ This ambiguity explains the p53 dependent and independent expression of p21 during cell growth, differentiation, and DNA damage. ${ }^{94}$ The increased expression of p21 or p 27 by cyclin D1 does not always result in cell cycle arrest, since the increased level of cyclin $\mathrm{D} 1$ :cdk4 can absorb more cki, ${ }^{88}{ }^{95}$ or may otherwise be associated with differentiation. ${ }^{92}$ Increased expression of p16 by E2F, however, results in displacement of cyclin $\mathrm{D}$ from cyclin
D:cdk complexes and in a rapid proteolysis of this protein, which leads to reduced levels or absence of cyclin D1. In this way mutation of $\mathrm{Rb}$ leads to absence of cyclin D1. ${ }^{96}{ }^{97}$

Adhesion mediated growth control

Most cell types require mitogenic growth factors as well as adhesion of cells onto extracellular matrix components for proliferation. ${ }^{15}$ Adhesion to extracellular matrix is mediated by integrins, which are transmembrane proteins that dimerise and undergo conformational changes by binding to extracellular matrix and thereby activate the integrin mediated signal pathway. ${ }^{98}$ This involves many yet undissolved steps and includes activation of focal adhesion associated kinase (FAK), which is connected through src and sos to the MAP kinase pathway (fig 7). ${ }^{917}$

Activation of integrins also leads to activation of Rho family members, including GTPases rac, cdc42, and rho, which are involved respectively in ruffling, formation of filopodia, and stress fibre formation-processes associated with rearrangement of the actin cytoskeleton that goes along with spreading of cells upon attachment to extracellular matrix. ${ }^{98}$ The GTPases ras and rho interact to regulate expression of cki-p21, where p21-as was mentioned above - is induced by ras, and rho negatively interferes with the induction of p21 by $\operatorname{ras}^{99}$ (fig 7). Growth factor stimulation then leads to two events: to activation of ras and thereby to p21 through growth factors in the medium; and to activation of rho through adherence to extracellular matrix in conjunction with serum factors, of which 

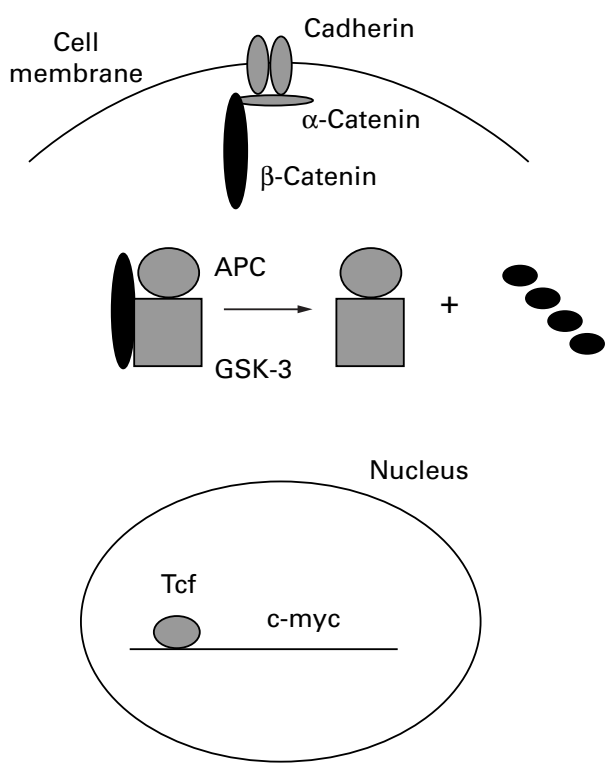

Normal cell

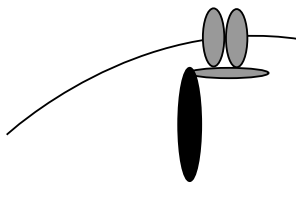

Muted or reduced

cadherin

or

mutated $\beta$-catenin

or

mutated APC
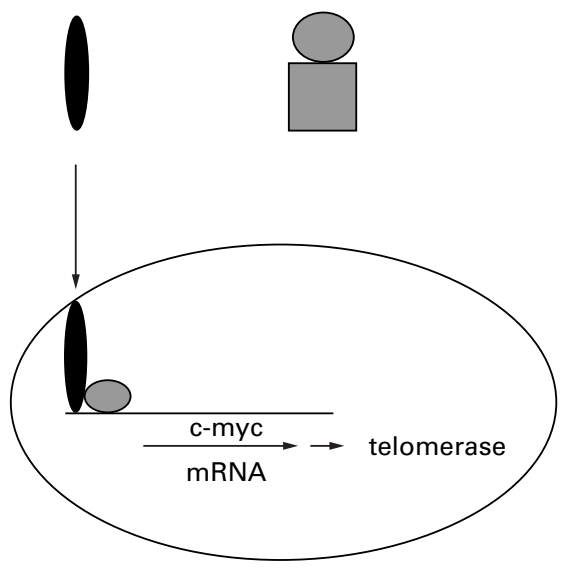

Tumour cell

Figure 8 The cadherin- $\beta$-catenin-Tcf-myc-telomerase pathway in tumour cells. APC, adenomatous polyposis coli suppressor; GSK, glycogen synthetase kinase.

lysophosphatidylic acid (LPA), is the most relevant factor. The other two GTPases, rac and cdc42, activate-most probably through activation of $\mathrm{p} 65^{\mathrm{PAK}}$ - the JunK pathway which leads to cyclin D1 expression and E2F dependent transcription. ${ }^{100}$ These recent findings indicate that adhesion independent growth of tumour cells may be caused by disruption of the $\mathrm{Rb}$ pathway, ${ }^{101-103}$ as is frequently encountered in tumour cells of advanced stage. ${ }^{14}$ Since sustained detachment of normal cells from the extracellular matrix usually leads to apoptosis, also in the presence of growth factors, ${ }^{104}{ }^{105}$ this is a relevant obstacle on the road to anchorage independent growth. Activation of FAK kinase and of the GTPases rac and cdc42 requires cellular attachment and spreading, ${ }^{106}$ and the latter demands dimerisation of integrins. Dimerisation of integrins may then be the crucial step in anchorage independent proliferation, which in $\mathrm{Rb}$ wild-type cells will not be overcome by overexpression of cyclins alone.

Not only does adhesion onto the extracellular matrix affect cell cycle regulation, but intercellular adhesion through cadherins also influences cell cycle regulation by cki-p27 and by the $\beta$-catenin-Tcf pathway. In normal cells intercellular binding through E-cadherin molecules results in binding of $\beta$-catenin to E-cadherin on the cellular membrane or to destruction of $\beta$-catenin by an APC/GSK3 complex formation (fig 8). ${ }^{107}$ In both cases entry of $\beta$-catenin into the nucleus is prevented. Mutation of APC or $\beta$-catenin, or either mutation or downregulation of E-cadherin, prevents degradation of $\beta$-catenin, which now moves to the nucleus and coactivates transcription factor $\mathrm{Tcf}$ to mediate transcription of, among other things, transcription factor $\mathrm{myc}^{108}$; myc induces transcription of telomerase, ${ }^{109}$ providing immortality to cells (see below), but also induces a yet unidentified factor which releases p27 mediated inhibition of cyclin E:cdk2 activity, thereby releasing p 27 mediated growth inhibition. ${ }^{110}$

\section{What else is up or down?}

Is this all there is to cell cycle control? A weekly glance in the journals might tell you that tumour cells have more options in store than we might think of. The emphasis in this review is on control over the G1/S phase of the cell cycle, since in this phase the cells are extremely sensitive to regulation by external factors. Once cells have traversed restriction point $\mathrm{R}$ (fig 2), cell cycle transition is autonomous-not that matters may not go wrong there as well! In fact, aneuploidy - the form of genetic instability characteristic of a more advanced tumour phenotype-is associated in colonic cancer, and probably in other tumour types as well, with loss of control over mitosis by mutational inactivation of the BUB1 gene, which in normal cells takes care of the proper segregation of the chromosomes. ${ }^{111}$ Furthermore, in a small number of tumours genetic instability is also caused by an increased mutation rate at nucleotide level, leading to microsatellite instability as a result of defective repair of DNA damage. ${ }^{112} 113$

Tumour development requires escape from clearing systems. To do this, tumour cells have to arrest apoptosis as well as downmodulate immunological defence systems. Escape from apoptosis is not only mandatory in order to escape from chemotherapy and radiotherapy, but tumour cells also have to overcome "natural" apoptosis invoked by hypoxia ${ }^{114}$ or detachment from extracellular matrix components. ${ }^{15}$ As more and more apoptosis regulatory pathways, and the genes involved, become known, ${ }^{115}$ deregulation of each of these genes may be required to prevent apoptosis in various 
Modes of deregulation in tumours:

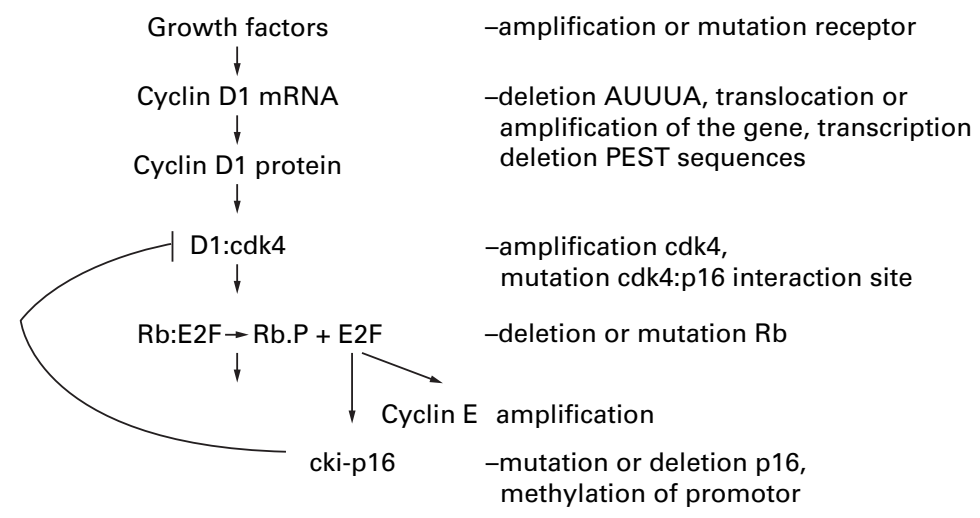

Figure 9 Deregulation of the Rb-cyclin D1-cdk4-p16 pathway in cancer.

types of tumours. Studies on transformation of cells by adenoviruses have shown how transforming proteins downregulate expression of HLA on the cell surface, thereby drastically reducing putative targets for immunological attack, in order to escape from such attack. ${ }^{116}$

However, even tumour cells would not escape from inevitable aging if they had not found a way of preventing ordinary mortality. The number of telomeric DNA repeats at the end of a chromosome is an unmistakable indication of the proliferative history of cells, since telomeres shorten progressively with each succeeding cell division owing to the switching off of telomerase activity. ${ }^{117}$ This telomerase activity becomes reactivated in tumour cells by, among other things, the activity of the myc transcription factor. ${ }^{109}$ In this respect, it is noteworthy that overexpression of myc often occurs in different tumour types, including colon, breast, head and neck, and lung cancer, and is associated with advanced stage of disease. ${ }^{118}$

In further progression of tumours, (re)activation of cell migration is a requirement for invasion and metastasis of tumour cells, which touches on regulation of adhesion, cell movement, and secretion of proteases in order to dissolve surrounding membranes. Derangement of expression of these genes adds to the genetic acrobatics in tumour cells.

\section{Essential derailments in cancer}

Tumour cells have undergone distortions in control over growth, apoptosis, and aging. The essential pathways in these are, respectively, the $\mathrm{Rb}$ pathway, $\mathrm{p} 53$, and telomerase (re)activation. Derailments in these pathways provide increasing autonomy for tumour cells and a selective advantage over other cells. For example, overexpression of cyclin D1 protein in MCF7 breast cancer cells renders these cells capable of proliferating under reduced serum concentrations by affecting the proportion of cells in the Go, quiescence state ${ }^{95}$ Overexpression of cyclin D1 prevents cells from entering quiescence and therefore enhances the proliferative fraction of tumour cells. Since tumour cells in vivo will encounter various growth factor conditions, overexpression of cyclin D1 most probably allows tumour cells to continue to proliferate in low growth factor conditions in vivo as well.

Distortion of the $\mathrm{Rb}$ pathway is a common phenomenon in cancer (see below), and is achieved by disruption of $\mathrm{Rb}$, overexpression of cyclin D1 or cdk4, or downregulation of cki-p16 (fig 9). Various mechanisms may account for these deregulations:

For $\mathrm{Rb}$ : point mutation, deletion, and functional inactivation by the binding of viral proteins at the site of interaction with cyclin:cdk.

For cyclin D1: amplification of the gene, inter- and intrachromosomal recombination, loss of destabilising sequences in the mRNA by deletion ${ }^{119}$ or alternative splicing, ${ }^{120}{ }^{121}$ or overexpression as a result of aberrant growth factor stimulation.

For p16: most often by deletion, infrequently by point mutation and by methylation of promoter sequences.

For cdk4: by amplification ${ }^{122}$ and by mutation of its interaction site with $\mathrm{p} 16 .^{123124}$

When one adds up all these possibilities and examines series of breast, lung, head and neck, or melanoma cancers for any of these alterations, one is likely to find that all tumours have undergone some distortion in the $\mathrm{Rb}$ pathway. ${ }^{125}$ The same accounts for disruption of the $\mathrm{p} 19^{\mathrm{ARF}}-\mathrm{p} 53$ pathway which prevents apoptosis from occurring, whereas most advanced carcinomas also show telomerase activation in order to become immortal. ${ }^{126}{ }^{127}$

\section{Clinical relevance of alterations in $\mathbf{R b}$, p53, and telomerase pathways}

Are the particular aberrations in these pathways relevant for the process of tumour progression and for treatment? To answer this, one would like to discern different stages of tumour progression according to genetic alterations in the different tumour types. This was ideally encountered in the case of progression of colonic cancer, where the different stages of progression from initial lesion to invasive phenotype can be studied within the same neoplasm. ${ }^{2}$ Here, progression by morphological criteria is paralleled by a stepwise accumulation of genetic alterations. Where this ideal situation is not met, as is the case in most other cancer types, cumulative association between frequency of genetic alterations and increased tumour stage yields a similar ranking of genetic alterations for progression of head and neck cancer, ${ }^{128}{ }^{129}$ whereas single associations underline (or undermine) the relevance of a particular genetic alteration in other tumour types.

Studies in which alterations in the primary tumours (without obvious dissemination) are associated with disease-free interval or with disease associated survival have many pitfalls, but are often used for want of other options. If a certain association turns out to be significant, one might wonder about its specific effect. For instance, overexpression of cyclin D1 protein is consistently associated with shortened diseasefree interval in squamous carcinomas of the head and neck (see below). In this tumour type, one hardly ever finds $\mathrm{Rb}$ mutation ${ }^{130}$ but rather often finds p16 mutations. ${ }^{131} 132$ Furthermore, 
Cyclin D1
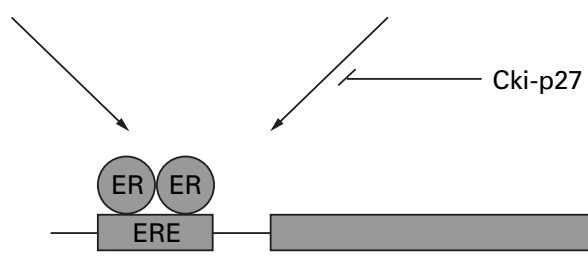

D1.cdk4

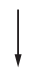

$\mathrm{Rb} . \mathrm{E} 2 \mathrm{~F} \longrightarrow \mathrm{Rb} . \mathrm{P}+\mathrm{E} 2 \mathrm{~F}$

Figure 10 Alternative activation of oestrogen receptor (ER) by cyclin D1 or cyclin A.cdk2.

most of these tumours lack a functional p53. Overexpression of cyclin D1 would only provide a selective advantage to cells when they are normal for $\mathrm{Rb}$ and lack expression of $\mathrm{p} 16$. On the other hand, expression of p16 would have no effect on cyclin $\mathrm{D} 1$ in $\mathrm{Rb}$ mutated cells. If one presumes that all lesions in squamous carcinoma of the head and neck originate from smoking or alcohol abuse, and that these neoplasms have circumvented p53 mediated arrest or apoptosis by mutation of p53, then a growth advantage would be acquired in $\mathrm{Rb}$ mutant cells or in cyclin $\mathrm{D} 1$ overexpressing cells with a mutation or reduced expression of p16. These tumour cells would be less dependent on growth factor stimulation or on adhesion onto extracellular matrix components. Why this reduced dependency in head and neck cancer is mainly achieved by overexpression of cyclin D1 and not by direct deregulation of $\mathrm{Rb}$ remains an enigma.

This example demonstates that the aim of discerning different stages of tumour progression according to genetic alterations is not likely to be fulfilled by examining just a single alteration, or only a few, but that a hierarchy of genetic alterations must be taken into account. In the $\mathrm{Rb}$ pathway this hierarchy includes: disruption of $\mathrm{pRb}$, overexpression of cyclin $\mathrm{D} /$ disruption of $\mathrm{p} 16$, and overexpression/ mutation of cdk4. These possibilities should be examined in conjunction with disruption of the p1 $19^{\mathrm{ARF}}-\mathrm{p} 53$ pathway, and other not yet fully explored major pathways of apoptosis induction, and with reactivation of telomerase. Only then may pathology based on gain or loss of functions provide a meaningful and conceptual replacement of an established pathology based on morphology, which is highly effective but lacks the power to predict the outcome of most lymph node negative tumours. It is not difficult to predict that rolling stones will descend from the mountain; it is a challenge to predict which ones will start to roll.

It might be clear from a limited and selected survey on some tumour systems given below that pathology is still in its infancy in making an inventory of these dysfunctions in tumours.

\section{Other activities of cyclins}

The major role of cyclin:cdk is to direct regulation of the cell cycle, but it is also becoming apparent that some cyclin:cdk complexes are also involved in other biological processes, which are indirectly associated with proliferation. Cyclin-H and cdk7, a cyclin:cdk complex which is not itself associated with a particular cell cycle transition, are part of the TFIIH nucleotide-excision complex, but are also identified as components of CAK. ${ }^{133}$

Cyclin E:cdk2 is associated with the spliceosome associated protein SAP 155, which is efficiently phosphorylated by cyclin E:cdk2 . This suggests that a fraction of cyclin E:cdk2 is involved in the splicing machinery of mRNA. ${ }^{134}$

Cyclin D binds directly to a myb-like transcription factor, DMP1, which becomes activated by phosphorylation through cyclin D:cdk activity, suggesting that the latter may also regulate gene expression in an $\mathrm{Rb}$ independent manner. ${ }^{135}$ Cyclin D1 also inhibits the activity of another transcription factor involved in myogenic differentiation, showing that it may affect transcription directly. ${ }^{136}$

Other jobs on the side carried out by cyclin D1 and cyclin A might be relevant for activation of the oestrogen receptor (fig 10). Cyclin D1 stimulates activation of the oestrogen receptor through direct binding unhampered by anti-oestrogens. ${ }^{137}$ This stimulation of the oestrogen receptor by cyclin D1 is cdk independent, ${ }^{137} 138$ in contrast with oestrogen receptor activation by cyclin A:cdk2, which requires cdk2 activity and is inhibited by cki-p27. ${ }^{139}$ These findings suggest that transcriptional activation of the oestrogen receptor may occur in the absence of oestradiol in cells with overexpression of cyclin D1 or cyclin A. However, for cyclin D1 to stimulate the oestrogen receptor, it should be present in a vast excess and in an unbound state, a situation that is hardly met in tumour cells (see above), and which may only result in transient transfections, but is probably absent in vivo.

\section{What does distortion of the $\mathrm{Rb}$ pathway do to cells?}

The idea that progression of the cell cycle through G1 to S requires only phosphorylation of $\mathrm{pRb}$ and thereby releases E2F turns out to be too simple. Cyclin E can overcome a p16 induced arrest of the cell cycle without phosphorylation of $\mathrm{pRb},{ }^{140}$ indicating that other targets of cyclin E:cdk2 activity determine the full transit through G1. It is not (yet) clear which other target this may be, but myc overexpression can do the same. ${ }^{141}$

In general, overexpression of cyclins $\mathrm{D} 1$ or $\mathrm{E}$ does lead to accelerated transition through $\mathrm{G} 1$, and overexpression of cyclin D1 does lead to reduced growth factor dependency and a reduced entry into Go, quiescence. Activation of E2F by overexpression of cyclin D1 or cyclin $\mathrm{E}$ leads to $\mathrm{p} 53$ dependent apoptosis under reduced serum conditions. ${ }^{76}$ In transformation assays, overexpression of cyclin D1 by itself is not sufficient to induce transformation, but it does so in conjunction with adenovirus E1A. ${ }^{142}$ In transgenic mouse models the effect of cyclin 
D1 overexpression does depend on the promoter that is used in the transgene. Use of the EBV promoter yields squamous cell carcinomas, ${ }^{143}$ that of immunoglobulin enhancer stimulates lymphoma development in conjunction with myc, ${ }^{144}$ and those of keratin in epidermal hyperproliferation ${ }^{145}$ and of mouse mammary tumour virus (MMTV) cause hyperplasia, ultimately leading to carcinoma development. ${ }^{146}$ But cyclin $\mathrm{E}$ in a transgene under control of the promoter of $\beta$ lactoglobulin also produces hyperplasia in the mammary gland. ${ }^{147}$ These data show that overexpression of cyclin D1 and of cyclin E alleviates growth restriction, but does not itself lead to transformation. Additional genetic alterations are mandatory for full transformation.

The absence of cyclin D is more helpful in demonstrating the subsidiary roles fulfilled by cyclins D: mice lacking cyclin D1 have reduced body size, show symptoms of retinal deformation, and fail to undergo proliferation of breast cells upon pregnancy (steroid) stimulation. ${ }^{148} 149$ Female mice lacking cyclin D2 are sterile owing to the inability of ovarian granulosa cells to proliferate in response to follicle stimulating hormone (FSH), whereas mutant males display hypoplastic testes. ${ }^{150}$ These data show that D-type cyclins are dispensable (mice lacking these D-type cyclins are still alive), and that other D-type cyclins most probably take over the role of the missing one. They further demonstrate that their subsidiary roles are not dispensable: for cyclin D1, this is activation of the oestrogen receptor in mammary gland development; for cyclin D2, it is activation of a yet to be determined pathway that is involved in testicular development.

The crucial role of $\mathrm{Rb}$ is underlined by the non-viability of $\mathrm{Rb}$ homozygous knock out mice, whereas heterozygotes display increased apoptosis and sensitivity to tumour development. ${ }^{151}$

A peculiar and somewhat overlooked aspect of overexpression of cyclin D1 is its ability to enhance gene amplification, ${ }^{152}$ which may well contribute to genomic instability.

\section{Derailments in tumors in vivo}

Many reviews have recently appeared describing distortions of the $\mathrm{Rb}$ and $\mathrm{p} 19^{\mathrm{ARF}}-\mathrm{p} 53$ pathway in different types of tumours. ${ }^{129}{ }^{153-156}$ The studies quoted below are only given to complement these and to illustrate novel tendencies.

Bladder cancer - In separate studies, prognosis of patients with bladder cancer was significantly poor when the primary tumour was less positive for $\mathrm{Rb},{ }^{157}$ or showed overexpression of cyclin D $1,{ }^{158}$ indicating that distortion of the $\mathrm{Rb}$ pathway contributes to poor prognosis.

Breast cancer-All of the disturbances in the $\mathrm{Rb} /$ cyclin D1/p16 pathway are encountered in breast cancer: abnormal (reduced or absent) $\mathrm{pRb}^{159} 160$ in $20 \%$ of non-invasive cancers, which was associated with increased proliferation rate and oestrogen receptor negativity; no loss or mutation of cki-p16 in primary breast cancer ${ }^{161}$ but frequent loss of $\mathrm{p} 16$ expression in approximately $45 \%$ of all breast cancer cases. ${ }^{159} 162163$ Overexpression of cyclin D1 in $40-50 \%$ of all cases, ${ }^{154155164}$ of which half is due to amplification of cyclin D1 on chromosome 11q13. This amplification, and corresponding overexpression, is associated with a more aggressive tumour phenotype and a worse prognosis. ${ }^{165-168}$ Overexpression of cyclin D1 protein or mRNA is noticed in high grade ductal carcinomas in situ, which show more frequent recurrences than low grade tumours, ${ }^{169} 170$ and it occurs in the vast majority of invasive lobular carcinomas, but not in noninvasive lobular carcinomas. ${ }^{171}$ However, overexpression of cyclin D1 protein was not by itself indicative of prognosis in large series of patients with a low stage of breast cancer. ${ }^{164}$ 172-174 This apparent contradiction may be explained by the fact that only approximately half of all cases with overexpression of cyclin D1 protein can be accounted for by amplification of the cyclin D1 gene, which is the most frequent genetic aberration and which is linked to poor prognosis. Since overexpression of cyclin D1 protein is highly significantly linked to oestrogen receptor, ${ }^{173-175}$ and since cyclin D1 is turned on by activated oestrogen receptor, the other half of the cases with overexpression of cyclin D1 protein in breast cancer may result from "normal" stimulation by oestradiol, the impact of which on breast cancer development remains to be investigated.

Co-overexpression of cyclin D1 together with epidermal growth factor receptor or $\mathrm{pRb}$ is more indicative of poor prognosis than expression of cyclin D1 alone. ${ }^{176}$

Aberrations in other cell cycle regulators are also becoming apparent in breast cancer. Cyclin $\mathrm{E}$ overexpression in $20 \%$ of non-invasive cancer is associated with a more aggressive phenotype, ${ }^{177} 178$ in particular in conjunction with low cyclin D1 expression. ${ }^{174}$ Cyclin E overexpression is prevalent in oestrogen receptor negative breast cancer cases, whereas $\mathrm{Rb}$ deletions occur only in this group of breast cancers. ${ }^{174} 177$

Reduction of cki-p27 expression, whether or not in conjunction with overexpression of cyclin $\mathrm{E}$, is indicative of poor prognosis in node negative breast cancer patients, ${ }^{179-182}$ and also in colonic cancer ${ }^{182}$ and prostate cancer. ${ }^{183} 184$

Inactivation of E-cadherin, which may lead to raised myc and activation of telomerase (see above), is often found in infiltrating lobular breast cancer, but not in other breast cancer types, ${ }^{185}$ promoting two steps in tumour progression: adherence independence and immortality.

Mutations in $\mathrm{p} 53$ releasing apoptotic control were found in 69 of 316 primary breast cancer cases and were significantly associated with poor prognosis. ${ }^{186-188}$ These studies also indicated that direct analysis of mutation has substantially better prognostic value than immunohistochemical overexpression of p53.

Only a few studies have dealt with interactions between deregulated cell cycle regulators, and have confirmed the experimental findings described above: the inverse relation between $\mathrm{pRb}$ and $\mathrm{p} 16,{ }^{159} 174$ the positive interaction between cyclin D1 and p21, ${ }^{92} 189190$ and the 


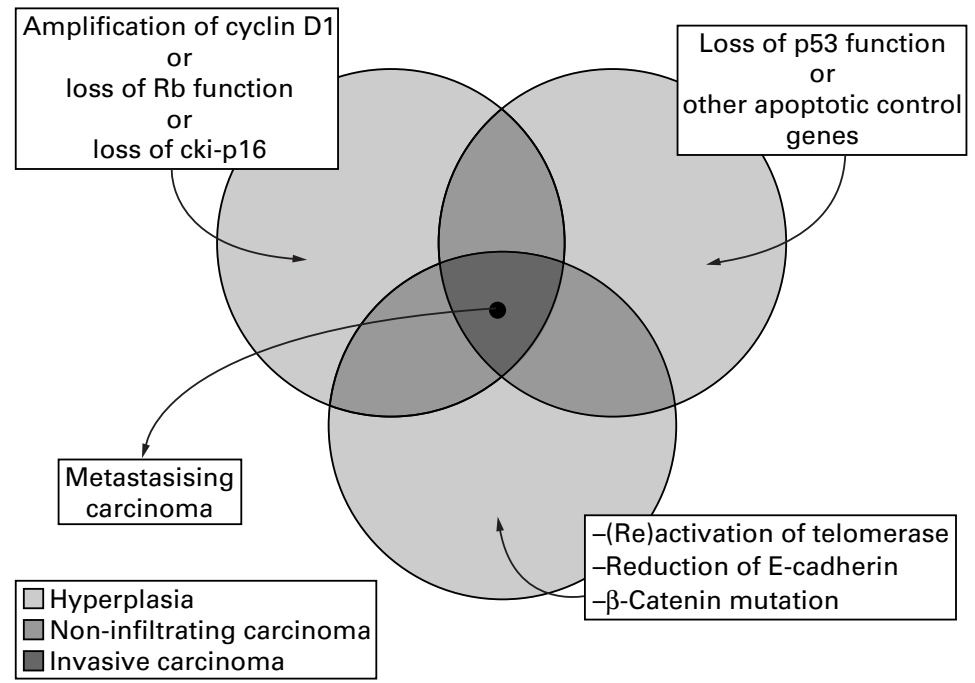

Figure 11 Molecular biological model for breast tumour progression.

absence of cyclin $\mathrm{D} 1$ in $\mathrm{Rb}$ negative tumours, ${ }^{160174} 189$ which now, however, do prevalently overexpress cyclin E. ${ }^{174}$

When one considers the model of tumour progression associated with deregulation of growth stimulation (the $\mathrm{Rb} / \mathrm{p} 16 /$ cyclin $\mathrm{D} 1$ pathway) and of apoptosis (among others, the p53 pathway), then none of these investigations examined whether combinations of such deregulations contribute to a more advanced stage, or whether they occur in more advanced stages of breast cancer. Interesting in this respect is the finding that overexpression of cyclin D1 did not coincide with mutation of p53 (measured by immunohistochemistry) in a series of 248 breast cancer patients of low stage. ${ }^{173}$ One would presume that progression of breast cancer in earlier stages may go along with either disturbed growth stimulation or disrupted apoptosis, and that more advanced breast cancer stages would represent mutations in both of these pathways and reactivation of telomerase. From this summary of published reports, a molecular biological model for progression of breast cancer may be derived, which is presented in fig 11 .

In this model, morphological hyperplasia may coincide with either loss of growth control by amplification of cyclin $\mathrm{D} 1$, by loss of $\mathrm{Rb}$ function, or by loss of p16; or with loss of control of apoptosis by loss of p53 function or by loss of other apoptosis regulating genes; or with loss of senescence control by reactivation of telomerase activity through upregulation of myc as a result of reduction of E-cadherin or mutation of $\beta$-catenin or APC. When two of these regulatory pathways have been demolished, these neoplasias may present as limited carcinoma in situ, whereas where all three pathways are affected, they may present as morphological carcinoma. When cells have undergone one particular mutation resulting in loss of growth control, there is no further selective advantage for additional mutations leading to loss of growth control. Mutations within one regulatory unit - either growth control, apoptosis, or senescence-are therefore usually mutually exclusive.
On top of this, additional mutations leading to aberrant expression of proteases or cell adhesion molecules affect the metastatic behaviour of tumour cells, resulting in invasive carcinomas.

Mantle cell lymphoma-Mantle cell lymphoma comprises approximately $10 \%$ of all non-Hodgkin lymphomas and represents a generalised disease with poor prognosis. More than $90 \%$ of these mantle cell lymphomas show overexpression of cyclin D1 as a result of $\mathrm{t}(11 ; 14)$ chromosomal translocations. ${ }^{191} 192$ This is a remarkable example of a sporadic tumour type in which almost $100 \%$ of the cases are consistently associated with a particular genetic aberration, namely overexpression of cyclin D1. This unique association allows the use of overexpression of cyclin D1 in the rather difficult morphological diagnosis of mantle cell lymphoma.

Squamous cell carcinomas of the head and neck and oesophagus-Amplification and overexpression of cyclin D1 or loss of cki-p16 is significantly associated with a more advanced tumour phenotype and with poor prognosis. ${ }^{129} 193-198$ In particular in tumours with $\mathrm{pRb}$ expression, overexpression of cyclin D1 is indicative of poor prognosis. ${ }^{196} 199$ Inactivation of either the apoptotic pathway (through p53) or the growth promoting pathway (through overexpression of cyclin D1) is associated with poor prognosis, whereas derailments of both these pathways are more prevalent in more advanced tumours (T4, stage IV). ${ }^{195}$ This indicates again that tumour progression coincides with cumulative deregulation of pathways controlling growth and apoptosis.

Immunohistochemical studies also confirm the experimental findings that overexpression of cyclin D1 is associated with increased expression of cki-p $27^{200}$ and in a p53 independent manner with cki-p21. ${ }^{201}$

Lung cancer-Whereas in small cell lung cancers $\mathrm{Rb}$ is often mutated, in non-small-cell lung cancer p16 and p27 status is a significant prognostic factor, and the lack of expression of these cki is associated with poor prognosis. ${ }^{202-206}$ Loss of $\mathrm{p} 19^{\mathrm{ARF}}$ is more common in small cell lung cancer than in non-small-cell lung cancer. ${ }^{207}$ The impact of $\mathrm{p} 19^{\mathrm{ARF}}$ mutations in cancer will undoubtedly become a new fishing pond.

Other types of tumour-Overexpression of cyclin D1 and mutation of p53 (assessed by immunohistochemistry) are independent prognostic factors in colonic cancer, ${ }^{208}{ }^{209}$ whereas overexpression of cyclin D1 is more prevalent in advanced stages ${ }^{210}$ and is associated with intestinal adenomas in patients with familial adenomatous polyposis. ${ }^{211}$ Lack of p16 expression or overexpression of cyclin D1 is associated with poor prognosis in pancreatic cancer. ${ }^{212} 213$ Overexpression of p53 and disturbances in the $R b$ pathway, either lack of $R b$ and p16 expression or overexpression of cyclin D1, were markers of poor prognosis in ovarian cancer. $^{214}{ }^{215}$ Remarkable was the high expression of p53 and p16 in Rb negative tumours (acting through E2F?). ${ }^{214}$ Furthermore, overexpression of cyclin D1 is indicative of poor 
prognosis in prostatic adenocarcinoma. ${ }^{216}$ In the light of the specific side effects mentioned above, aberrant expression of cyclin D2 is particularly associated with testicular tumour development. ${ }^{217}$

This incomplete list of distortions in the $\mathrm{pRb}$ and $\mathrm{p} 53$ pathways in different types of cancer shows that deviations in these pathways are linked to tumour progression. Because in most studies only one or a few of the players have been examined, it is not yet always clear which of these disturbances (if any) are the most informative indicators of poor prognosis, and why. The mass of evidence that one or other of these deregulations contributes to a poor prognosis in different types of cancer suggests that a modern approach to risk assessment should involve an evaluation of these markers in prospective studies.

\section{Cell cycle regulators and sensitivity to cytostatic agents and radiation}

Since cell cycle regulators also influence sensitivity to agents which either cause arrest of the cell cycle or induce apoptosis (see above), one might presume an intrinsic dependency between these. Sensitivity of cells towards cytostatic agents or radiation has until now mostly been studied with respect to p53 status. Loss of p53 function in tumour cells indeed confers increased resistance to chemotherapy or radiation. $^{218-221}$ The connection between E2F and $\mathrm{p} 53$ by way of $\mathrm{p} 19^{\mathrm{ARF}}$ has now been revealed, and both of them induce either $\mathrm{p} 21$ or apoptosis; thus a costimulatory effect is most likely to occur when cells with a normal p53 and $\mathrm{Rb}$ are being treated with growth factors together with cytostatic agents, as has indeed been reported for taxol and radiation..$^{82} 83222$ One might predict that deregulation of the $\mathrm{pRb}$ pathway would render tumour cells with intact p $19^{\mathrm{ARF}}-\mathrm{p} 53$ more sensitive to these agents, whereas mutation of $\mathrm{p} 19^{\mathrm{ARF}}$ alone would eliminate any costimulational effect of growth factors by way of E2F. Inventories of this kind have hardly begun to be made, but might well turn out to be essential for assessment of a more effective form of drug treatment.

\section{Conclusion}

This overview indicates that an inventory of the essential deregulations in the cell cycle regulators adds to a better understanding of the genesis of different types of cancer. Data are accumulating that these deregulations are associated with the development of specific types of cancer and with their clinical behaviour. This may well lead to the development of specific cancer treatments and to improved efficacy of existing treatments, and should therefore become a must in molecular pathology.

I thank Mrs Marieke van der Velde for secretarial assistance and Tom Verschoor for art work. The author's research is supported by grants from the Netherlands Cancer Foundation.

1 Vogelstein B, Kinzler KW. The genetic basis of human cancer. Vogelstein B, Kinzler KW. The ge

2 Fearon ER. Human cancer syndromes: clues to the origin and nature of cancer. Science 1997;278:1043-50.
3 Pardee AB. G1 events and regulation of cell proliferation. Science 1989;246:603-8.

4 Morgan DO. Cyclin-dependent kinases: engines, clocks, and microprocessors. Annu Rev Cell Dev Biol 1997;13:26191

5 Jackman MR, Pines JN. Cyclins and the G2/M transition. Cancer Surv 1997;29:47-73.

6 Sherr CJ. D-type cyclins. Trends Biol Sci 1995;20:187-90.

7 Herber B, Truss $M$, Beato $M$, et al. Inducible regulatory elements in the human cyclin D1 promoter. Oncogene 1994;9: 2105-7.

8 Watanabe G, Albanese C, Lee RJ, et al. Inhibition of cyclin D1 kinase activity is associated with E2F-mediated inhibition of cyclin D1 promoter activity through E2F and Sp1. Mol Cell Biol 1998;18:3212-22.

9 Hunter T. Oncoprotein networks. Cell 1997;88:333-46.

10 Roussel MF. Key effectors of signal transduction and G1 Roussel MF. Key effectors of signal transd
progression. Adv Cancer Res 1998;74:1-24.

11 Lukas J, Bartkova J, Bartek J. Convergence of mitogenic signalling cascades from diverse classes of receptors at the cyclin D-cyclin-dependent kinase-pRb-controlled G1 checkpoint. Mol Cell Biol 1996;16:6917-25.

12 Altucci L, Addeo R, Cicatiello L, et al. 17beta-Estradiol induces cyclin D1 gene transcription, p36D1-p34cdk4 complex activation and $\mathrm{p} 105 \mathrm{Rb}$ phosphorylation during mitogenic stimulation of $\mathrm{G}(1)$-arrested human breast cancer cells. Oncogene 1996;12:2315-24.

13 Brown JR, Nigh E, Lee RJ, et al. Fos family members induce cell cycle entry by activating cyclin D1. Mol Cell Biol 1998; 18:5609-19.

14 Assoian RK. Anchorage-dependent cell cycle progression. $\mathcal{f}$ Cell Biol 1997;136:1-4.

15 Bottazzi ME, Assoian RK. The extracellular matrix and mitogenic growth factors control G1 phase cyclins and cyclin-dependent kinase inhibitors. Trends Cell Biol 1997;7: 348-52.

16 St Croix B, Sheehan CE, Rak JW, et al. E-cadherindependent growth suppression is mediated by the cyclindependent kinase inhibitor p2 $7^{\mathrm{KIP} 1}$. I Cell Biol 1998;142: 557-71.

17 Schlaepfer DD, Hanks SK, Hunter T, et al. Integrinmediated signal transduction linked to Ras pathway by GRB2 binding to focal adhesion kinase. Nature 1994;372: 786-91.

18 Quelle DE, Ashmun RA, Shurtleff SA, et al. Overexpression of mouse D-type cyclins accelerates G1 phase in rodent fibroblasts. Genes Dev 1993;7:1559-71.

19 Lukas J, Bartkova J, Rohde M, et al. Cyclin D1 is dispensable for G1 control in retinoblastoma gene-deficient cells independently of cdk4 activity. Mol Cell Biol 1995;15:260011.

20 Arber N, Doki Y, Han EK, et al. Antisense to cyclin D1 inhibits the growth and tumorigenicity of human colon cancer cells. Cancer Res 1997;57:1569-74.

21 Weinberg RA. The retinoblastoma protein and cell cycle control. Cell 1995;81:323-30.

22 Beijersbergen RL, Carlee L, Kerkhoven RM, et al. Regulation of the retinoblastoma protein-related p107 by Regulation of the retinoblastoma protein-related p

23 Herrera RE, Sah VP, Williams BO, et al. Altered cell cycle kinetics, gene expression, and G1 restriction point regulation in Rb-deficient fibroblasts. Mol Cell Biol 1996;16:2402-7.

24 Muller H, Lukas J, Schneider A, et al. Cyclin D1 expression is regulated by the retinoblastoma protein. Proc Natl Acad Sci USA 1994;91:2945-9.

25 Schulze A, Zerfass K, Spitkovsky D, et al. Cell cycle regulation of the cyclin A gene promoter is mediated by a variant E2F site. Proc Natl Acad Sci USA 1995;92:11264-8.

26 Ohtani K, DeGregori J, Nevins JR. Regulation of the cyclin E gene by transcription factor E2F1. Proc Natl Acad Sci USA 1995;92:12146-50.

27 Kitagawa M, Higashi H, Jung HK, et al. The consensus motif for phosphorylation by cyclin D1-Cdk4 is different from that for phosphorylation by cyclin $\mathrm{A} / \mathrm{E}-\mathrm{Cdk} 2 . E M B O$ 7 1996;15:7060-9.

28 Resnitzky A, Reed SI. Different roles for cyclin D1 and E in regulation of the G1-to-S transition. Mol Cell Biol 1995;15: 3463-9

29 Ohtsubo M, Theodoras AM, Schumacher J, et al. Human cyclin E, a nuclear protein essential for the G1-to-S phase transition. Mol Cell Biol 1995;15:2612-24.

30 Bernards R. E2F: a nodal point in cell cycle regulation. Biochim Biophys Acta 1997;1333:M33-40.

31 Moberg K, Starz MA, Lees JA. E2F-4 switches from p130 to p107 and pRB in response to cell cycle reentry. Mol Cell Biol 1996;16:1436-49.

32 Hurford RK, Cobrinik D, Lee MH, et al. pRB and p107/p130 are required for the regulated expression of different sets of E2F responsive genes. Genes Dev 1997;11: 1447-63.

33 Connell-Crowley L, Elledge SJ, Harper JW. G1 cyclindependent kinases are sufficient to initiate DNA synthesis in quiescent human fibroblasts. Curr Biol 1998;8:65-8.

34 Johnson DG, Schwarz JK, Cress WD, et al. Expression of transcription factor E2F1 induces quiescent cells to enter S phase. Nature 1993;365:349-52.

35 Yan Z, DeGregori J, Shohet R, et al. Cdc6 is regulated by $\mathrm{E} 2 \mathrm{~F}$ and is essential for DNA replication in mammalian cells. Proc Natl Acad Sci USA 1998;95:3603-8.

36 Romanowski P, Madine MA. Mechanisms restricting DNA replication to once per cell cycle: the role of Cdc6p and ORC. Trends Cell Biol 1997;7:9-10. 
37 Krek W, Xu G, Livingston DM. Cyclin A-kinase regulation of E2F-1 DNA binding function underlies suppression of of E2F-1 DNA binding function underlies supp
an S phase checkpoint. Cell 1995;83:1149-58.

38 Guadagno TM, Newport JW. Cdk2 kinase is required for entry into mitosis as a positive regulator of Cdc2-cyclin B kinase activity. Cell 1996;84:73-82.

39 Hunter T, Pines J. Cyclins and cancer II: cyclin D and CDK inhibitors come of age. Cell 1994;79:573-82.

40 Diehl JA, Sherr CJ. A dominant-negative cyclin D1 mutant prevents nuclear import of cyclin-dependent kinase 4 (CDK4) and its phosphorylation by CDK-activating kinase. Mol Cell Biol 1997;17:7362-74.

41 Won KA, Reed SI. Activation of cyclin E/CDK2 is coupled to site-specific autophosphorylation and ubiquitindependent degradation of cyclin. EMBO $\mathcal{f}$ 1996;15:418293.

42 Hoyt MA. Eliminating all obstacles: regulated proteolysis in the eukaryotic cell cycle. Cell 1997;91:149-51.

43 Diehl JA, Zindy F, Sherr CJ. Inhibition of cyclin D1 phosphorylation on threonine-286 prevents its rapid degradation via the ubiquitin-proteasome pathway. Genes Dev 1997:11:957-72.

44 Harper JW. Cyclin dependent kinase inhibitors. Cancer Surv 1997;29:91-107.

45 Elledge SJ, Winston J, Harper JW. A question of balance: the role of cyclin-kinase inhibitors in development and tumorigenesis. Trends Cell Biol 1996;6:388-92.

46 Sherr CJ, Roberts JM. Inhibitors of mammalian G1 cyclindependent kinases. Genes Dev 1995;9:1149-63.

47 Coleman KG, Wautlet BS, Morrissey D, et al. Identification of CDK4 sequences involved in cyclin D1 and p16 binding. F Biol Chem 1997;272:18869-74.

48 Sherr CJ. G1 phase progression: cycling on cue. Cell 1994:79:551-5.

49 Sherr CJ. Cancer cell cycles. Science 1996;274:1672-7.

50 Blain SW, Montalvo E, Massague J. Differential interaction of the cyclin-dependent kinase (Cdk) inhibitor p27Kip1 with cyclin A-Cdk2 and cyclin D2-Cdk4. F Biol Chem 1997;272:25863-72.

51 Harper JW, Elledge SJ, Keyomarsi K, et al. Inhibition of cyclin-dependent kinases by p21. Mol Biol Cell 1995;6: 387-400.

52 LaBaer J, Garrett MD, Stevenson LF, et al. New functional activities for the p21 family of CDK inhibitors. Genes Dev 1997;11:847-62.

53 Sandhu C, Garbe J, Bhattacharya N, et al. Transforming growth factor beta stabilizes p15INK4B protein, increases p15INK4B-cdk4 complexes, and inhibits cyclin D1-cdk4 association in human mammary epithelial cells. Mol Cell Biol 1997; 17:2458-67.

54 Planas-Silva MD, Weinberg RA. Estrogen-dependent cyclin E-cdk2 activation through p21 redistribution. Mol Cell Biol 1997;17:4059-69.

55 Prall OWJ, Sarcevic B, Musgrove EA, et al. Estrogeninduced activation of Cdk 4 and Cdk2 during G1-S phase progression is accompanied by increased cyclin D1 expression and decreased cyclin-dependent kinase inhibito association with cyclin E-Cdk2. I Biol Chem 1997;272: 10882-94

56 Hashemolhosseini S, Nagamine Y, Morley SJ, et al. Rapamycin inhibition of the G1 to $\mathrm{S}$ transition is mediated by effects on cyclin D1 mRNA and protein stability. $\mathcal{F}$ Biol Chem 1998;273:14424-9.

57 Niculescu AB, Chen X, Smeets $\mathrm{M}$, et al. Effects of p21(Cip1/Waf1) at both the G1/S and the G2/M cell cycle transitions: $\mathrm{pRb}$ is a critical determinant in blocking DNA replication and in preventing endoreduplication $\mathrm{Mol} \mathrm{Cell}$ Biol 1998;18:629-43 [published erratum appears in $\mathrm{Mol}$ Cell Biol 1998;18:1763].

58 Dulic V, Stein GH, Farahi Far D, et al. Nuclear accumulation of $\mathrm{p} 21 \mathrm{Cip} 1$ at the onset of mitosis: a role at accumulation of p21Cipl at the onset of mitosis: a role at

59 Levine AJ. p53, the cellular gatekeeper for growth and division. Cell 1997; 88:323-31.

60 O'Connor PM. Mammalian G1 and G2 phase checkpoints. Cancer Surv 1997;29:151-82.

61 Lane DP. Cancer. A death in the life of p53. Nature 1993;362:786-7.

62 White E. Tumour biology. p53, guardian of Rb. Nature 1994;371:21-2.

63 Lane DP. Awakening angels. Nature 1998;394:616-17.

64 Woo RA, McLure KG, Lees-Miller SP, et al. DNAdependent protein kinase acts upstream of p53 in response to DNA damage. Nature 1998;394:700-4

65 Banin S, Moyal L, Shieh S-Y, et al. Enhanced phosphorylation of p 53 by ATM in response to DNA damage. Science tion of p53 by ATM

66 Qin XQ, Livingston DM, Kaelin WG, et al. Deregulated transcription factor E2F-1 expression leads to S-phase entry and p53-mediated apoptosis. Proc Natl Acad Sci USA 1994;91:10918-22.

67 Fan J, Bertino JR. Functional roles of E2F in cell cycle regulation. Oncogene 1997;14:1191-200.

68 Hiebert SW, Packham G, Strom DK, et al. E2F-1:DP-1 induces p53 and overrides survival factors to trigger apoptosis. Mol Cell Biol 1995;15:6864-74.

69 Chen J, Wu X, Lin J, et al. mdm-2 inhibits the G1 arrest and apoptosis functions of the p53 tumor suppressor protein. Mol Cell Biol 1996;16:2445-52.

70 Kamijo T, Zindy F, Roussel MF, et al. Tumor suppression at the mouse INK4a locus mediated by the alternative the mouse INK4a locus mediated by the altern

71 Bates S, Phillips AC, Clark PA, et al. p14 ${ }^{\mathrm{ARF}}$ links the tumour suppressors RB and p53. Nature 1998;395:124-5.
72 Palmero I, Pantoja C, Serrano M. p19 $9^{\text {ARF }}$ links the tumour suppressor p53 to Ras. Nature 1998;395:125-6.

73 Zindy F, Eischen CM, Randle DH, et al. Myc signaling via the ARF tumor suppressor regulates p53-dependent apoptosis and immortalization. Genes Dev 1998;12:2424-33.

74 de Stanchina E, McCurrach ME, Zindy F, et al. E1A signaling to $\mathrm{p} 53$ involves the p19(ARF) tumor suppressor. Genes Dev 1998;12:2434-42.

75 Chin L, Pomerantz J, DePinho RA. The INK4a/ARF tumor suppressor: one gene-two products-two pathways. Trends Biol Sci 1998;23:291-6.

76 Sofer-Levi Y, Resnitzky D. Apoptosis induced by ectopic expression of cyclin D1 but not cyclin E. Oncogene expression of cycl.

77 Phillips AC, Bates S, Ryan KM, et al. Induction of DNA synthesis and apoptosis are separable functions of E2F-1. Genes Dev 1997;11:1853-63.

78 Shan B, Durfee T, Lee WH. Disruption of RB/E2F-1 interaction by single point mutations in E2F-1 enhances S-phase entry and apoptosis. Proc Natl Acad Sci USA 1996; 93:679-84.

79 Tishler RB, Lamppu DM, Park S, et al. Microtubule-active drugs taxol, vinblastine, and nocodazole increase the levels of transcriptionally active p53. Cancer Res 1995;55:6021-5.

80 Hawkins DS, Demers GW, Galloway DA. Inactivation of p53 enhances sensitivity to multiple chemotherapeutic agents. Cancer Res 1996;56:892-8.

81 Pardo FS, Su M, Borek C. Cyclin D1 induced apoptosis maintains the integrity of the G1/S checkpoint following onizing radiation irradiation. Somat Cell Mol Genet 1996;22:135-44.

82 Coco-Martin JM, Balkenende A, Verschoor T, et al. Cyclin D1 overexpression enhances radiation-induced apoptosis and radiosensitivity in a breast tumor cell line. Cancer Res 1999;59:1134-40

83 Michalides R, Tiemessen M, Verschoor T, et al. Overexpression of cyclin D1 enhances paclitaxel induced apoptosis.

84 Shapiro GI, Edwards CD, Ewen ME, et al. p16INK4A participates in a G1 arrest checkpoint in response to DNA damage. Mol Cell Biol 1998;18:378-87.

85 Massague J. TGF-beta signal transduction. Annu Rev Biochem 1998;67:753-9.

$86 \mathrm{Li} \mathrm{Y,} \mathrm{Nichols} \mathrm{MA,} \mathrm{Shay} \mathrm{JW,} \mathrm{et} \mathrm{al.} \mathrm{Transcriptional} \mathrm{repression}$ of the D-type cyclin-dependent kinase inhibitor p16 by the retinoblastoma susceptibility gene product pRb. Cancer Res 1994;54:6078-82.

87 Lukas J, Parry D, Aagaard L, et al. Retinoblastoma-proteindependent cell-cycle inhibition by the tumour suppressor p16. Nature 1995;375:503-6.

88 Hiyama H, Iavarone A, LaBaer J, et al. Regulated ectopic expression of cyclin D1 induces transcriptional activation of the cdk inhibitor p21 gene without altering cell cycle progression. Oncogene 1997;14:2533-42.

89 Liu Y, Martindale JL, Gorospe $\mathrm{M}$, et al. Regulation of p21WAF1/CIP1 expression through mitogen-activated protein kinase signaling pathway. Cancer Res 1996;56:31-5.

90 Serrano M, Lin AW, McCurrach ME, et al. Oncogenic ras provokes premature cell senescence associated with accumulation of p53 and p16INK4a. Cell 1997;88:593-602

91 Hiyama H, Iavarone A, Reeves SA. Regulation of the cdk inhibitor p21 gene during cell cycle progression is under the control of the transcription factor E2F. Oncogene 1998; 16:1513-23

92 De Jong JS, van Diest PJ, Michalides R, et al. Concerted overexpression of p21 and cyclin D1 is associated with growth inhibition and differentiation in various carcinomas. I Clin Pathol Mol Pathol (in press).

93 Han EK, Begemann M, Sgambato A, et al. Increased expression of cyclin D1 in a murine mammary epithelial cell line induces p27kip1, inhibits growth, and enhances apoptosis. Cell Growth Differ 1996;7:699-710.

94 Macleod KF, Sherry N, Hannon G, et al. p53-dependent and independent expression of $\mathrm{p} 21$ during cell growth, difand independent expression of p21 during cell growth, dif-

95 Zwijsen RM, Klompmaker R, Wientjens EB, et al. Cyclin D1 triggers autonomous growth of breast cancer cells by governing cell cycle exit. Mol Cell Biol 1996;16:2554-60.

96 Parry D, Bates S, Mann DJ, et al. Lack of cyclin D-Cdk complexes in Rb-negative cells correlates with high levels of p16INK4/MTS1 tumour suppressor gene product. $E M B O$ 7 1995; 14:503-11.

97 Bates S, Parry D, Bonetta L, et al. Absence of cyclin D/cdk complexes in cells lacking functional retinoblastoma protein. Oncogene 1994;9:1633-40.

98 Keely P, Parise L, Juliano R. Integrins and GTPases in tumour cell growth, motility and invasion. Trends Cell Biol 1998;8:101-6.

99 Olson MF, Paterson HF, Marshall CJ. Signals from Ras and Rho GTPases interact to regulate expression of $\mathrm{p} 21^{\text {Waf1/Cip1 }}$ Nature 1998;394:295-8

100 Gjoerup O, Lukas J, Bartek J, et al. Rac and Cdc42 are potent stimulators of E2F-dependent transcription capable of promoting retinoblastoma susceptibility gene product hyperphosphorylation. F Biol Chem 1998;273:18812-18.

101 Resnitzky D. Ectopic expression of cyclin D1 but not cyclin $\mathrm{E}$ induces anchorage-independent cell cycle progression. Mol Cell Biol 1997;17:5640-7.

102 Zhu X, Ohtsubo M, Bohmer RM, et al. Adhesiondependent cell cycle progression linked to the expression of cyclin D1, activation of cyclin E-cdk2, and phosphorylation cyclin D1, activation of cyclin E-cdk2, and phosphorylation
of the retinoblastoma protein. F Cell Biol 1996;133:391403. 
103 Fang F, Orend G, Watanabe N, et al. Dependence of cyclin E-CDK2 kinase activity on cell anchorage. Science $6 ; 271: 499-502$.

104 Frisch SM, Francis H. Disruption of epithelial cell-matrix interactions induces apoptosis. F Cell Biol 1994;124:619-26.

105 Cardone MH, Salvesen GS, Widmann C, et al. The regulation of anoikis: MEKK-1 activation requires cleavage by caspases. Cell 1997;90:315-23.

106 Clark EA, King WG, Brugge JS, et al. Integrin-mediated signals regulated by members of the rho family of GTPases. f Cell Biol 1998;142:573-86.

107 Morin PJ, Sparks AB, Korinek V, et al. Activation of betacatenin-Tcf signaling in colon cancer by mutations in betacatenin or APC. Science 1997;275:1787-90.

$108 \mathrm{He}$ TC, Sparks AB, Rago C, et al. Identification of c-MYC as a target of the APC pathway. Science 1998;281:1509-12.

109 Wang J, Xie LY, Allan S, et al. Myc activates telomerase. Genes Dev 1998;12:1769-74.

110 Muller D, Bouchard C, Rudolph B, et al. Cdk2-dependent phosphorylation of p27 facilitates its Myc-induced release from cyclin E/cdk2 complexes. Oncogene 1997;15:2561-76.

111 Cahill DP, Lengauer C, Yu J, et al. Mutations of mitotic checkpoint genes in human cancers. Nature 1998;392:3003.

112 Liu B, Parsons R, Papadopoulos N, et al. Analysis of mismatch repair genes in hereditary non-polyposis colorectal cancer patients. Nature Med 1996;2:169-74.

113 Lengauer C, Kinzler KW, Vogelstein B. Genetic instability in colorectal cancers. Nature 1997;386:623-7.

114 Graeber TG, Osmanian C, Jacks T, et al. Hypoxiamediated selection of cells with diminished apoptotic potential in solid tumours. Nature 1996;379:88-91.

115 Evan G, Littlewood T. A matter of life and cell death. Science 1998;281:1317-22.

116 Schrier PI, Bernards R, Vaessen RT, et al. Expression of class I major histocompatibility antigens switched off by highly oncogenic adenovirus 12 in transformed rat cells. Nature 1983;305:771-5.

117 Shay JW, Wright WE. The reactivation of telomerase activity in cancer progression. Trends Genet 1996;12:129-31.

118 Schwab M. Amplification of oncogenes in human cancer cells. Bioessays 1998;20:473-9.

119 Hosokawa Y, Suzuki R, Joh T, et al. A small deletion in the 3'-untranslated region of the cyclin D1/PRAD1/bcl-1 oncogene in a patient with chronic lymphocytic leukemia. Int f Cancer 1998;76:791-6.

120 Sawa H, Ohshima TA, Ukita H, et al. Alternatively spliced forms of cyclin D1 modulate entry into the cell cycle in an inverse manner. Oncogene 1998;16:1701-12.

121 Betticher DC, Thatcher N, Altermatt HJ, et al. Alternate splicing produces a novel cyclin D1 transcript. Oncogene 1995;11:1005-11.

$122 \mathrm{He} \mathrm{J}$, Allen JR, Collins VP, et al. CDK4 amplification is an alternative mechanism to p16 gene homozygous deletion in glioma cell lines. Cancer Res 1994;54:5804-7.

123 Tsao H, Benoit E, Sober AJ, et al. Novel mutations in the p16/CDKN2A binding region of the cyclin-dependent p16/CDKN2A binding region of the cyclin
kinase-4 gene. Cancer Res 1998;58:109-13.

124 Schmidt EE, Ichimura K, Reifenberger G, et al. CDKN2 (p16/MTS1) gene deletion or CDK4 amplification occurs in the majority of glioblastomas. Cancer Res 1994;54:6321-4.

125 Bartek J, Bartkova J, Lukas J. The retinoblastoma protein pathway and the restriction point. Curr Opin Cell Biol 1996;8:805-14

126 Tang R, Cheng A-J, Wang J-Y, et al. Close correlation between telomerase expression and adenomatous polyp Res 1998;58:4052-4.

127 Snijders PJF, van Duin M, Walboomers JMM, et al. Telomerase activity exclusively in cervical carcinomas and a subset of cervical intraepithelial neoplasia grade III lesions: strong association with elevated messenger RNA levels of strong association with elevated messenger RNA levels of
its catalytic subunit and high-risk human papillomavirus its catalytic subunit and high-risk
DNA. Cancer Res 1998;58:3812-18.

128 Califano J, van der Riet P, Westra W, et al. Genetic progression model for head and neck cancer: implications for field cancerization. Cancer Res 1996;56:2488-92.

129 Michalides RJ. Molecular basis of neoplasia. In: Jones AS Phillips DE, and Hilges FJM, eds. Diseases of the nose and throat. London: Arnold, 1998:87-105.

130 Yoo GH, Xu HJ, Brennan JA, et al. Infrequent inactivation of the retinoblastoma gene despite frequent loss of chromosome $13 \mathrm{q}$ in head and neck squamous cell carcinoma. Cancer Res 1994;54:4603-6.

131 Olshan AF, Weissler MC, Pei H, et al. Alterations of the p16 gene in head and neck cancer: frequency and
association with p53, PRAD-1 and HPV. Oncogene 1997; 14:811-18.

132 Reed AL, Califano J, Cairns P, et al. High frequency of p16 (CDKN2/MTS-1/INK4A) inactivation in head and neck squamous cell carcinoma. Cancer Res 1996;56:3630-3.

133 Poon RY, Hunter T. Cell regulation. Innocent bystanders or chosen collaborators? Curr Biol 1995;5:1243-7.

134 Seghezzi W, Chua K, Shanahan F, et al. Cyclin E associates with components of the pre-mRNA splicing machinery in mammalian cells. Mol Cell Biol 1998;18:4526-36.

135 Hirai H, Sherr CJ. Interaction of D-type cyclins with a novel myb-like trans

136 Rao SS, Chu C, Kohtz DS. Ectopic expression of cyclin D1 prevents activation of gene transcription by myogenic D1 prevents activation of gene transcription by myogenic
basic helix-loop-helix regulators. Mol Cell Biol 1994;14: 5259-67.
137 Zwijsen RM, Wientjens E, Klompmaker R, et al. CDK-independent activation of estrogen receptor by

138 Neuman E, Ladha $\mathrm{MH}$, Lin $\mathrm{N}$, et al. Cyclin D1 stimulation of estrogen receptor transcriptional activity independent of cdk4. Mol Cell Biol 1997;17:5338-47.

139 Trowbridge JM, Rogatsky I, Garabedian MJ. Regulation of estrogen receptor transcriptional enhancement by the cyclin A/Cdk2 complex. Proc Natl Acad Sci USA 1997;94: $10132-7$.

140 Alevizopoulos K, Vlach J, Hennecke S, et al. Cyclin E and c-Myc promote cell proliferation in the presence of p16INK4a and of hypophosphorylated retinoblastoma family proteins. $E M B O \mathcal{F} 1997 ; 16: 5322-33$.

141 Vlach J, Hennecke S, Alevizopoulos K, et al. Growth arrest by the cyclin-dependent kinase inhibitor $\mathrm{p} 27^{\mathrm{Kip} 1}$ is abrogated by c-Myc. EMBO ₹ 1996;15:6595-604.

142 Hinds PW, Dowdy SF, Eaton EN, et al. Function of a human cyclin gene as an oncogene. Proc Natl Acad Sci USA 1994;91:709-13.

143 Mueller A, Odze R, Jenkins TD, et al. A transgenic mouse model with cyclin D1 overexpression results in cell cycle, epidermal growth factor receptor, and p53 abnormalities. Cancer Res 1997;57:5542-9.

144 Lovec H, Grzeschiczek A, Kowalski MB, et al. Cyclin $\mathrm{D} 1 / \mathrm{bcl}-1$ cooperates with myc genes in the generation of B-cell lymphoma in transgenic mice. EMBO $f$ 1994;13: 3487-95.

145 Robles AI, Larcher F, Whalin RB, et al. Expression of cyclin D1 in epithelial tissues of transgenic mice results in epidermal hyperproliferation and severe thymic hyperplasia. Proc Natl Acad Sci USA 1996;93:7634-8.

146 Wang TC, Cardiff RD, Zukerberg L, et al. Mammary hyperplasia and carcinoma in MMTV-cyclin D1 transgenic mice. Nature 1994;369:669-71

147 Bortner DM, Rosenberg MP. Induction of mammary gland hyperplasia and carcinomas in transgenic mice expressing human cyclin E. Mol Cell Biol 1997;17:453-9.

148 Sicinski P, Donaher JL, Parker SB, et al. Cyclin D1 provides a link between development and

149 Fantl V, Stamp G, Andrews A, et al. Mice lacking cyclin D1 are small and show defects in eye and mammary gland development. Genes Dev 1995;9:2364-72.

150 Sicinski P, Donaher JL, Geng Y, et al. Cyclin D2 is an FSH-responsive gene involved in gonadal cell proliferation and oncogenesis. Nature 1996;384:470-4.

151 Jacks T, Fazeli A, Schmitt EM, et al. Effects of an Rb mutation in the mouse. Nature 1992;359:295-300.

152 Zhou P, Jiang W, Weghorst CM, et al. Overexpression of cyclin D1 enhances gene amplification. Cancer Res 1996;56:36-9.

153 Michalides RJ. Deregulation of the cell cycle in lung cancer. In: Brambilla C, Brambilla E, eds. Lung tumors: fundamental biology and clinical management. New York: Marcel Dekker, 1998:211-26.

154 Michalides R. Deregulation of cyclin D1 in cancer. In: Mihich E, Croce C, eds. The biology of tumors. New York: Plenum Press, 1998.

155 Hall M, Peters G. Genetic alterations of cyclins, cyclindependent kinases, and Cdk inhibitors in human cancer. Adv Cancer Res 1996;68:67-108.

156 Donnellan R, Chetty R. Cyclin D1 and human neoplasia. Mol Pathol 1998;51:1-7.

157 Lipponen PK, Liukkonen TJ. Reduced expression of retinoblastoma $(\mathrm{Rb})$ gene protein is related to cell proliferation and prognosis in transitional-cell bladder cancer. 7 Cancer Res Clin Oncol 1995;121:44-50.

158 Shin KY, Kong G, Kim WS, et al. Overexpression of cyclin D1 correlates with early recurrence in superficial bladder cancers. Br F Cancer 1997;75:1788-92.

159 Dublin EA, Patel NK, Gillett CE, et al. Retinoblastoma and p16 proteins in mammary carcinoma: their relationship to cyclin D1 and histopathological parameters. Int $\mathcal{F}$ Cancer 1998;79:71-5.

160 Jares P, Rey MJ, Fernandez PL, et al. Cyclin D1 and retinoblastoma gene expression in human breast carcinoma: correlation with tumour proliferation and oestrogen receptor status. F Pathol 1997;182:160-6.

$161 \mathrm{Xu} \mathrm{L}$, Sgroi D, Sterner CJ, et al. Mutational analysis of CDKN2 (MTS1/pl6ink4) in human breast carcinomas. Cancer Res 1994;54:5262-4.

162 Geradts J, Kratzke RA, Niehans GA, et al. Immunohistochemical detection of the cyclin-dependent kinase inhibitor
2/multiple tumor suppressor gene 1 (CDKN2/MTS1) product p16INK4A in archival human solid tumors: correlation with retinoblastoma protein expression. Cancer Res 1995;55:6006-11.

163 Geradts J, Wilson PA. High frequency of aberrant p16(INK4A) expression in human breast cancer. Am $\mathcal{F}$ Pathol 1996;149:15-20.

164 van Diest PJ, Michalides RJ, Jannink I, et al. Cyclin D1 expression in invasive breast cancer: correlations and prognostic value. Am f Pathol 1997;150:705-11.

165 Seshadri R, Lee CS, Hui R, et al. Cyclin D1 amplification is not associated with reduced overall survival in primary breast cancer but may predict early relapse in patients with features of good prognosis. Clin Cancer Res 1996;2:117784.

166 Courjal F, Louason G, Speiser P, et al. Cyclin gene amplification and overexpression in breast and ovarian cancers: evidence for the selection of cyclin D1 in breast and cyclin $\mathrm{E}$ in ovarian tumors. Int $\mathcal{f}$ Cancer 1996;69:247-53. 
167 Tsuda H, Hirohashi S, Shimosato Y, et al. Correlation between long-term survival in breast cancer patients and amplification of two putative oncogene-coamplification 3104-8.

168 Schuuring E, Verhoeven E, van Tinteren H, et al. Amplification of genes within the chromosome $11 \mathrm{q} 13$ region is indicative of poor prognosis in patients with operable breas cancer. Cancer Res 1992;52:5229-34.

169 Weinstat-Saslow D, Merino MJ, Manrow RE, et al. Overexpression of cyclin D mRNA distinguishes invasive and in situ breast carcinomas from non-malignant lesions. Nature Med 1995;1:1257-60.

170 Simpson JF, Quan DE, O'Malley F, et al. Amplification of CCND1 and expression of its protein product, cyclin D1, in ductal carcinoma in situ of the breast. Am f Pathol 1997; in ductal carcis

171 Oyama T, Kashiwabara K, Yoshimoto K, et al. Frequent overexpression of the cyclin D1 oncogene in invasive lobu-

172 Gillett C, Smith P, Gregory W, et al. Cyclin D1 and prognosis in human breast cancer. Int $\mathcal{F}$ Cancer 1996;69:92-9.

173 Michalides R, Hageman P, van Tinteren $\mathrm{H}$, et al. A clinicopathological study on overexpression of cyclin D1 and of p53 in a series of 248 patients with operable breast cancer. Br f Cancer 1996;73:728-34.

174 Nielsen NH, Emdin SO, Cajander J, et al. Deregulation of cyclin E and D1 in breast cancer is associated with inactivation of the retinoblastoma protein. Oncogene 1997;14: vation of 304 .

175 Hui R, Cornish AL, McClelland RA, et al. Cyclin D1 and estrogen receptor messenger RNA levels are positively correlated in primary breast cancer. Clin Cancer Res 1996;2: 923-8.

176 McIntosh GG, Anderson JJ, Milton I, et al. Determination of the prognostic value of cyclin D1 overexpression in breast cancer. Oncogene 1995;11:885-91.

177 Scott KA, Walker RA. Lack of cyclin E immunoreactivity in non-malignant breast and association with proliferation in breast cancer. Br f Cancer 1997;76:1288-92.

178 Keyomarsi K, O’Leary N, Molnar G, et al. Cyclin E, a potential progn

179 Porter PL, Malone KE, Heagerty PJ, et al. Expression of cell-cycle regulators p27Kip 1 and cyclin $\mathrm{E}$, alone and in combination, correlate with survival
patients. Nature Med 1997;3:222-5.

180 Catzavelos C, Bhattacharya N, Ung YC, et al. Decreased levels of the cell-cycle inhibitor p27Kip1 protein: prognostic implications in primary breast cancer. Nature Med 1997;3:227-30

181 Tan P, Cady B, Wanner M, et al. The cell cycle inhibitor p27 is an independent prognostic marker in small (T1a,b)

82 Fredive breast carcinomas. Cancer Res 1997;57:1259-63. sion of p27(kip1) and cyclin D1 in some human breast cancer cells: inverse correlation between the expression of p27(kip1) and degree of malignancy in human breast and p27(kip1) and degree of malignancy in human breast and

183 Tsihlias J, Kapusta LR, DeBoer G, et al. Loss of cyclin-dependent kinase inhibitor p27Kip1 is a novel progcyctic factor in localized human prostate adenocarcinoma. Cancer Res 1998;58:542-8.

184 Cote RJ, Shi YF, Groshen S, et al. Association of $\mathrm{p} 27^{\mathrm{Kip}}$ levels with recurrence and survival in patients with stage $C$ prostate carcinoma. F Natl Cancer Inst 1998;90:916-20.

185 Berx G, Cleton-Jansen AM, Strumane K, et al. E-cadherin is inactivated in a majority of invasive human lobular breast cancers by truncation mutations throughout its extracellular domain. Oncogene 1996;13:1919-25.

186 Sjogren S, Inganas M, Norberg T, et al. The p53 gene in breast cancer: prognostic value of complementary DNA sequencing versus immunohistochemistry. I Natl Cancer Inst 1996;88:173-82.

187 Kovach JS, Hartmann A, Blaszyk H, et al. Mutation detection by highly sensitive methods indicates that p 53 gene mutations in breast cancer can have important prognostic value. Proc Natl Acad Sci USA 1996;93:1093-6.

188 Falette N, Paperin MP, Treilleux I, et al. Prognostic value of P53 gene mutations in a large series of node-negative breast cancer patients. Cancer Res 1998;58:1451-5.

189 Barbareschi M, Pelosio P, Caffo O, et al. Cyclin-D1-gene amplification and expression in breast carcinoma: relation with clinicopathologic characteristics and with retinoblastoma gene product, p53 and p21WAF1 immunohistooma gene product, p53 and p21WAF1 immuno
chemical expression. Int $\mathcal{f}$ Cancer 1997;74:171-4.

190 Rey MJ, Fernandez PL, Jares P, et al. p21WAF1/Cip1 is associated with cyclin D1CCND 1 expression and tubular associated with cyclin DICCND1 expression and tubular differentiation but is independent of p53 overexpress
human breast carcinoma. F Pathol 1998;184:265-71.

191 Swerdlow SH, Yang WI, Zukerberg LR, et al. Expression of cyclin D1 protein in centrocytic/mantle cell lymphomas with and without rearrangement of the BCL1/cyclin D1 gene. Hum Pathol 1995;26:999-1004

192 de Boer CJ, van Krieken JH, Schuuring E, et al. Bcl-1/cyclin D1 in malignant lymphoma. Ann Oncol 1997; 8:109-17.

193 Michalides RJ, Van Veelen N, Hart A, et al. Overexpression of cyclin D1 correlates with recurrence in a group of fortyseven operable squamous cell carcinomas of the head and neck. Cancer Res 1995;55:975-8.

194 Michalides RJ, van Veelen R, Kristel P, et al. Overexpression of cyclin D1 indicates a poor prognosis in squamous cell carcinoma of the head and neck. Arch Otolaryngol Head Neck Surg 1997;123:497-502.

195 Nogueira CP, Dolan RW, Gooey J, et al. Inactivation of p53 and amplification of cyclin D1 correlate with clinical outcome in head and neck cancer. Laryngoscope 1998;108: $345-50$

196 Ishikawa T, Furihata M, Ohtsuki Y, et al. Cyclin D1 overexpression related to retinoblastoma protein expression as a prognostic marker in human oesophageal squamous cell carcinoma. Br f Cancer 1998;77:92-7.

197 Meredith SD, Levine PA, Burns JA, et al. Chromosome $11 \mathrm{q} 13$ amplification in head and neck squamous cell carcinoma. Association with poor prognosis. Arch Otolaryngol Head Neck Surg 1995;121:790-4.

198 Masuda M, Hirakawa N, Nakashima T, et al. Cyclin D1 overexpression in primary hypopharyngeal carcinomas. Cancer 1996;78:390-5.

199 Takes RP, Baatenburg de Jong RJ, Schuuring E, et al. Markers for assessment of nodal metastasis in laryngeal carcinoma. Arch Otolaryngol Head Neck Surg 1997;123: $412-19$

200 Doki Y, Imoto M, Han EK, et al. Increased expression of the P27KIP1 protein in human esophageal cancer cell lines that over-express cyclin D1. Carcinogenesis 1997;18:113948

201 Nadal A, Jares P, Cazorla M, et al. p21WAF1/Cip1 expression is associated with cell differentiation but not with p53 mutations in squamous cell carcinomas of the larynx. $f$ Pathol 1997;183:156-63.

202 Taga S, Osaki T, Ohgami A, et al. Prognostic value of the immunohistochemical detection of p16INK4 expression in nonsmall cell lung carcinoma. Cancer 1997;80:389-95.

203 Okamoto A, Hussain SP, Hagiwara K, et al. Mutations in the p16INK4/MTS1/CDKN2, p15INK4B/MTS2, and p18 genes in primary and metastatic lung cancer. Cancer Res 1995;55:1448-51.

204 Esposito V, Baldi A, De Luca A, et al. Prognostic role of the cyclin-dependent kinase inhibitor p27 in non-small cell lung cancer. Cancer Res 1997;57:3381-5.

205 Yatabe Y, Masuda A, Koshikawa T, et al. p27KIP1 in human lung cancers: differential changes in small cell and non-small cell carcinomas. Cancer Res 1998;58:1042-7.

206 Gazzeri S, Gouyer V. Inactivation of RB gene and pRB function in lung cancer. In: Brambilla C, Brambilla E, eds. Lung tumors: fundamental biology and clinical management. New York: Marcel Dekker, 1998

207 Gazzeri S, Della Valla V, Chaussade L, et al. The human p $19^{\mathrm{ARF}}$ protein encoded by the beta transcript of the p16 $6^{I N K 4 A}$ gene is frequently lost in small cell lung cancer. Cancer Res 1998;58:3926-31.

208 Maeda K, Chung YS, Kang SM, et al. Overexpression of cyclin D1 and p53 associated with disease recurrence in colorectal adenocarcinoma. Int f Cancer 1997;74:310-15.

209 Maeda K, Chung Y, Kang S, et al. Cyclin D1 overexpression and prognosis in colorectal adenocarcinoma. Oncology 1998;55:145-51.

210 Bartkova J, Lukas J, Strauss M, et al. The PRAD-1/cyclin D1 oncogene product accumulates aberrantly in a subset of colorectal carcinomas. Int 7 Cancer 1994;58:568-73.

211 Zhang T, Nanney LB, Luongo C, et al. Concurrent overexpression of cyclin D1 and cyclin-dependent kinase 4 (Cdk4) in intestinal adenomas from multiple intestinal neoplasia (Min) mice and human familial adenomatous polyposis patients. Cancer Res 1997;57:169-75

212 Gansauge S, Gansauge F, Ramadani M, et al. Overexpression of cyclin D1 in human pancreatic carcinoma is associated with poor prognosis. Cancer Res 1997;57:1634-7.

213 Naka T, Kobayashi M, Ashida K, et al. Aberrant p16INK4 expression related to clinical stage and prognosis in patients with pancreatic cancer. Int $f$ Oncol 1998;12:1111-16.

214 Dong Y, Walsh MD, McGuckin MA, et al. Reduced expression of retinoblastoma gene product $(\mathrm{pRB})$ and high expression of $\mathrm{p} 53$ are associated with poor prognosis in ovarian cancer. Int 7 Cancer 1997;74:407-15.

215 Barbieri F, Cagnoli M, Ragni N, et al. Expression of cyclin D1 correlates with malignancy in human ovarian tumours. Br f Cancer 1997;75:1263-8.

216 Kallakury BV, Sheehan CE, Ambros RA, et al. The prognostic significance of $\mathrm{p} 34 \mathrm{cdc} 2$ and cyclin D1 protein expression in prostate adenocarcinoma. Cancer 1997;80: 753-63.

217 Houldsworth J, Reuter V, Bosl GJ, et al. Aberrant expression of cyclin D2 is an early event in human male germ cell tumorigenesis. Cell Growth Differ 1997;8:293-9.

218 Aas T, Borresen AL, Geisler S, et al. Specific P53 mutations are associated with de novo resistance to doxorubicin in breast cancer patients Plasminogen and wound healing. Inactivation of p53 enhances sensitivity to multiple chemotherapeutic agents. Cancer Res 1996;56: $892-8$.

219 Righetti SC, Della Torre G, Pilotti S, et al. A comparative study of p53 gene mutations, protein accumulation, and esponse to cisplatin-based chemotherapy in advanced ovarian carcinoma. Cancer Res 1996;56:689-93.

220 Rusch V, Klimstra D, Venkatraman E, et al. Aberrant p53 expression predicts clinical resistance to cisplatin-based chemotherapy in locally advanced non-small cell lung cancer. Cancer Res 1995;55:5038-42.

221 Wu SG, el-Deiry WS. p53 and chemosensitivity. Nature Med 1996;2:255-6.

222 Blagosklonny MV, el-Deiry WS. Acute overexpression of wt p53 facilitates anticancer drug- induced death of cancer and normal cells. Int $\mathcal{f}$ Cancer 1998;75:933-40. 